\title{
Exploring the sanctuary of Venus and its sacred grove: politics, cult and identity in Roman Pompeii
}

\author{
by Maureen Carroll
}

The temple and sacred grove of the patron divinity of a Roman town could function rather like an abbreviated symbol of the town itself. Depictions on Roman coins and illustrated maps sometimes show a temple belonging to the tutelary god or goddess of a particular city, the temple being flanked by trees or situated next to a colonnaded grove (Wroth, 1899: no. 29, pl. 16.13; no. 46, pl. 16.14; Levi, 1967: 154-8, pl. 9; Sear, 1982: no. 4142). Such landscaped sanctuaries were not only an expression of religious belief, but also of political identity and power. It is well documented that plants and vegetation in public architecture could be highly symbolic and politically charged (Carroll, 2003: 55-9, 124-5; Macaulay-Lewis, 2008; Pollard, 2009).

Whilst a variety of written and pictorial sources attest to the existence of Roman temple groves in many places, there has been little archaeological evidence to help us visualize them. The ample courtyard of the temple of Venus on the Via Marina in Pompeii became the focus of our excavations, as it offered crucial potential for advancing our knowledge about sacred groves (PLATE 1). Given the close connection between the sanctuary of the tutelary god of a community and the expression of political identity through it, the grove in this sanctuary had a special meaning, as Venus was the patron goddess of Pompeii.

Although no traces of plantings were detected in the original excavations between 1889 and 1900 or in later investigations, it appeared unlikely that the largest Roman temple in Pompeii, dedicated to a goddess who was associated closely with fertility, would have lacked a garden or grove (Sogliano, 1899; Mau, 1900; Sogliano, 1900; Maiuri, 1948: 7-8; Maiuri, 1960: 173-6). Fortunately, the subsoil of the sanctuary courtyard was still largely intact when we began work there in 1998, and unambiguous archaeological evidence for plantings in the sanctuary could be retrieved in all three fieldwork seasons (FIG. 1). It is one of three sites in Pompeii where excavations have demonstrated the existence of a sacred grove, the others being the suburban temple of Dionysos at Sant'Abbondio and the temple of Apollo west of the forum (Jashemski, 1979: 157-8; Jashemski, 1993: 253-4; Carroll and Godden, 2000).

Deep excavation and stratigraphic research in open spaces is extremely important for the information that can be gained about early Roman and pre-Roman occupation sequences and the processes of change in Pompeii, 


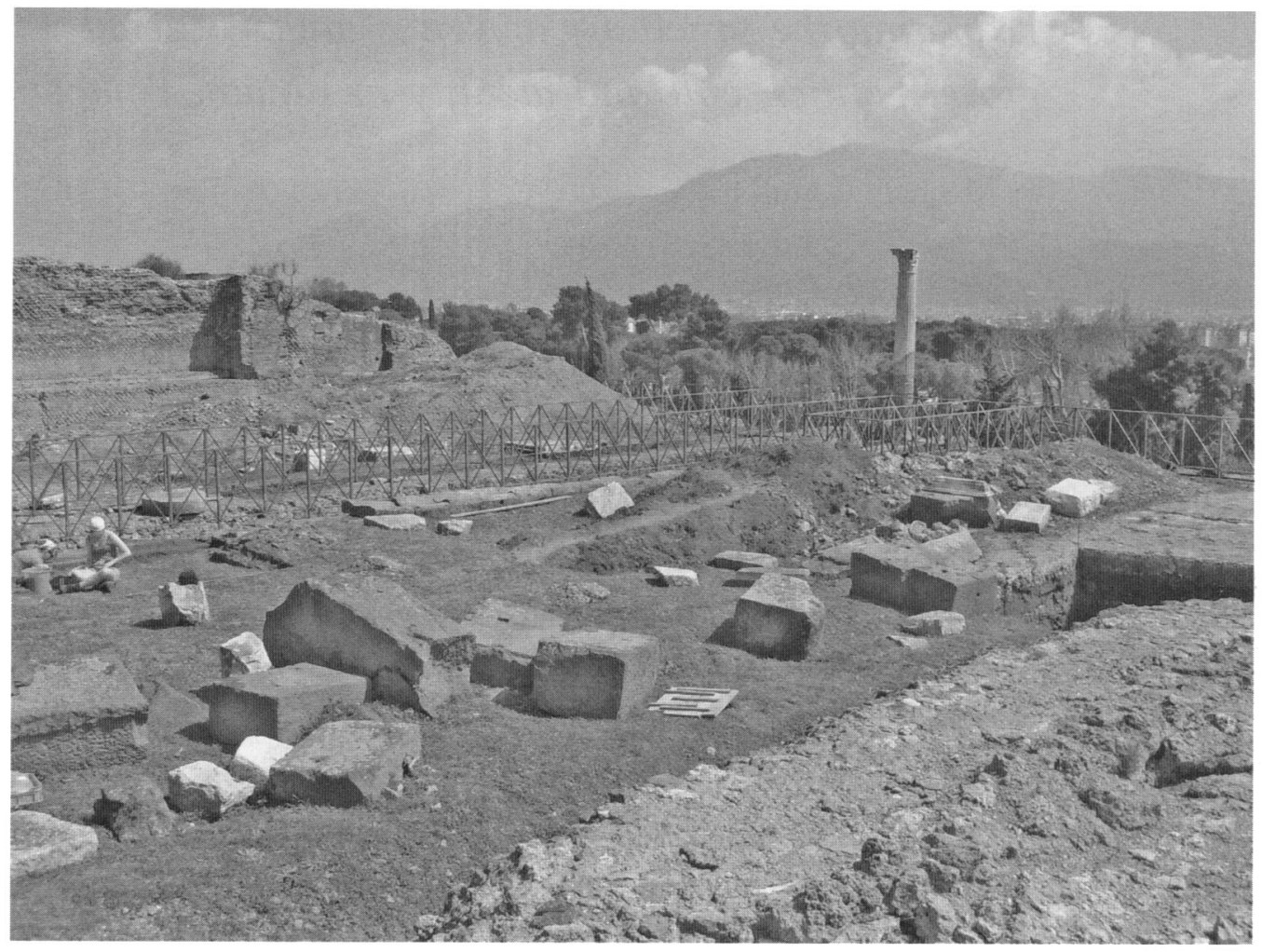

FIG. 1. Looking from the northern end of the temple of Venus across the eastern half of the courtyard, where excavations took place in 1998, 2004 and 2006. (Photo: author.)

especially since excavations in the past tended to focus on revealing the appearance of the city in $\mathrm{AD} 79$, when it was destroyed by the eruption of Vesuvius. The results of investigations of the subsoil below the destruction horizon often have necessitated a revision of the conventional chronological framework for the city's monuments (Bonghi Jovino, 1984; Bon et al., 1997; Carafa, 1997; Berry, 1998; Fulford and Wallace Hadrill, 1998; Fulford and Wallace-Hadrill, 1999; Carroll and Godden, 2000). The sanctuary of Venus had potential in this regard too, but our plans to explore the site for information on the early occupation and use of the area were complicated by the fact that from 2005 the Soprintendenza Archeologica di Pompei granted permits to excavate to both the University of Sheffield (Maureen Carroll) and the Università degli Studi della Basilicata, Matera (Emanuele Curti). In order to avoid conflicts, the temple precinct was 'divided' horizontally into the upper, Roman contexts (Sheffield), and the lower, pre-Roman contexts (Matera); this meant that we could not excavate as deeply as we originally had intended to. Nevertheless, most of our trenches reached a depth of at least $1 \mathrm{~m}$, and the cleaning and recording of sections left by older excavations and soil removal allowed us to explore deposits and structures to a depth of more than $2.5 \mathrm{~m}$. The results of the two excavations contradict each other in significant ways, to which we shall return below; in particular Curti states categorically (2008a: 58, n. 26) that 'non è alcuna evidenza' for a sacred grove at the site. 
In fact, our excavations have shed light not only on the sacred grove, but also on various important aspects related to the early development of the precinct. A preliminary report on the evidence for the sacred grove was published by the author in 2008, and the documentation of the excavation is available online; here I would like to contextualize those findings and expand on ideas and arguments relevant to the sanctuary of Venus and its significance for Pompeii (Carroll, 2008). ${ }^{1}$ In the ensuing discussion, therefore, the following themes are considered: when the sanctuary of Venus was conceived and established; how the temple precinct was landscaped and how it relates to the design of other temple complexes; how the sanctuary was altered in the Imperial period; and, finally, how the sanctuary was important in expressing Pompeii's political and religious identity.

\section{The TERRACE SANCTUARY OF VENUS AND ITS CHRONOLOGY}

In its elevated position on a slope, the Pompeian sanctuary is related to a group of imposing terrace sanctuaries in central Italy built in the second and early first centuries BC. These include the sanctuaries of Aesculapius at Fregellae (175-150 BC), Fortuna Primigenia at Praeneste (c. 125-100 BC), Diana Nemorensis at Nemi (c. 100 BC), Jupiter or Venus at Terracina (80s BC), and Hercules Victor at Tivoli (80s BC) (Fasolo and Gullini, 1953; Hanson, 1959: 29-36; Giuliani, 1970; Coarelli, 1986; Coarelli, 1987b; Ghini, 1993; Ghini, 1995; Ghini, 2000). Ultimately, the inspiration for such expansive terrace sanctuaries came from temple precincts in the Hellenistic east (Williams Lehmann, 1954; Rakob, 1976; Sear, 1983; Lauter, 1986: 105-12). But is the temple of Venus an Italian reflection of such Greek Hellenistic terrace sanctuaries and a creation of a pre-Roman period? If so, is the sanctuary to be understood as an expression of political self-presentation and economic prosperity in Samnite Pompeii in the second or early first century $B C$ ? This is what Curti $(2005 ; 2008 a)$ has proposed. Our investigations, however, point in a very different direction, to the creation of the temple terrace only after Pompeii became a Roman colony under Sulla in $80 \mathrm{BC}$ and was forced to accommodate Roman veterans and their families. The colonial date and context of the sanctuary enable us to understand the community's use of religious space in a period of changing social and political circumstances.

The temple was constructed of tuff and masonry in opus incertum, and, although later alterations to the building hinder an accurate reconstruction of the superstructure, it is clear that the temple had a porch and stairs leading up on the south side. Porticoes made of tuff surrounded the temple on the north, west and east sides (FIG. 2). Although the sanctuary faced south to overlook the valley below, it is unknown whether there were access ramps or stairs leading up to the front of the temple, because substructures erected in the first century AD obscured the original arrangements. The only recognizable entrance is that from the Via Marina at the corner of the northern and eastern porticoes; although the entrance in its present form is of Imperial date, the existence

1 See Carroll, 2008; http://www.shef.ac.uk/archaeology/research/venus/index.html (last consulted 23.08.2010). 

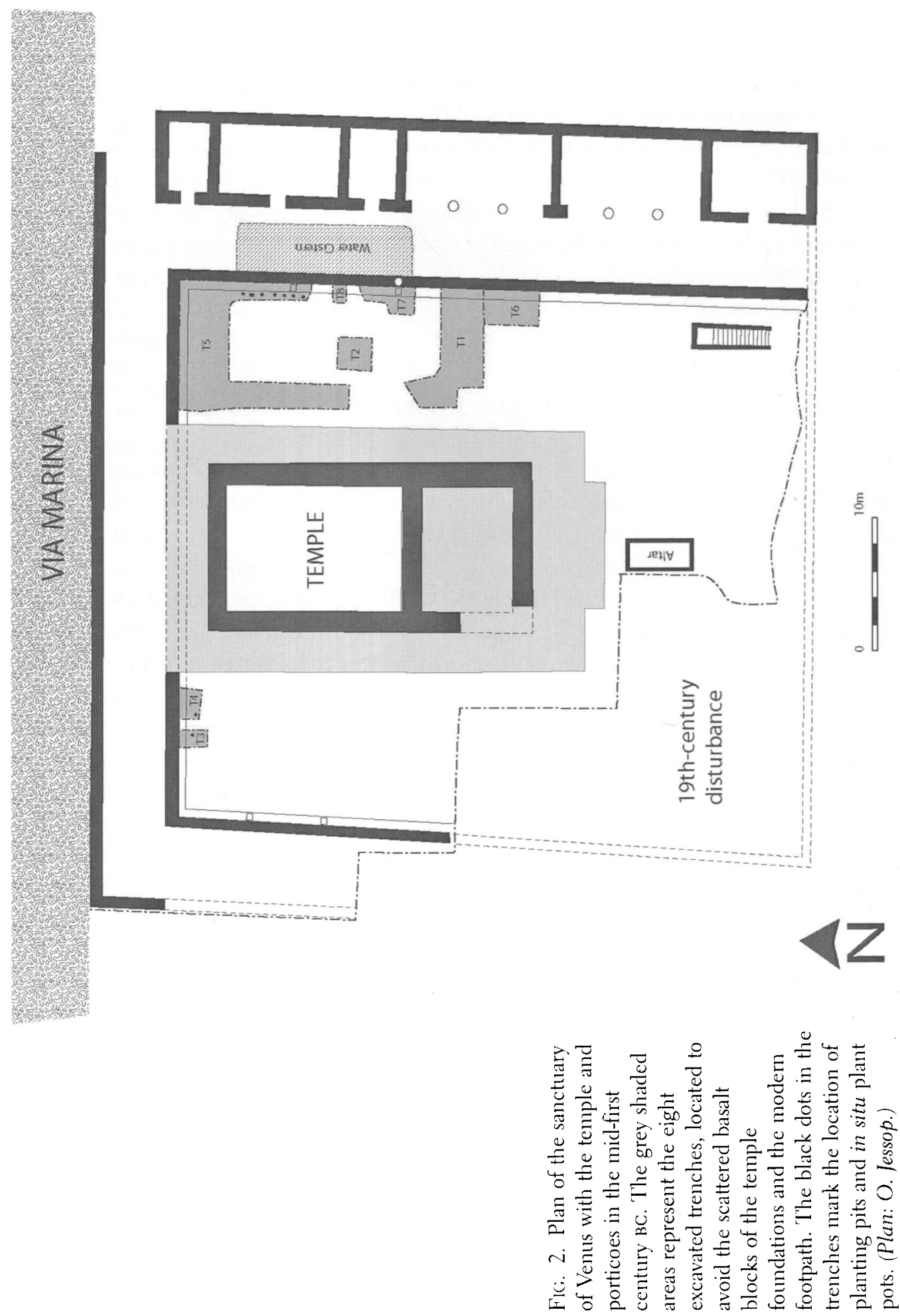
of an earlier entrance may be indicated by a gap between the original northern precinct wall on the edge of the Via Marina and the northern end of the east portico. The later post-earthquake precinct wall extends well into the original width of this street (see below). Parallel to and just in front of the stylobate of the porticoes was a shallow tuff gutter collecting rainwater from the portico roof; settling basins of the same material were inserted into the gutter at varying intervals. Under the floor of the eastern portico was a large vaulted cistem lined with hydraulic cement (FIG. 3). This was fed by rainwater from the gutter and a (partially excavated) stone-built channel that originated somewhere west of the cistern and sloped down to the east to empty into it. Spano (1910) mentioned a second large cistern in the western part of the complex; both of them, like other cisterns in public and sacred precincts, will have supplied water for the sanctuary and for the town in general as an emergency measure (Eschebach and Eschebach, 1995: 127, n. 452; Carroll and Godden, 2000: 744, 750-1).

The Roman temple of Venus was not the first structure built in this part of the city. A narrow trench for underground electric cables on the westem edge of the sanctuary uncovered preRoman remains and structures of the fourth and third centuries (Arthur, 1986; Cottica and Curti, 2008). Visible remains of other walls still stand in the southwestern part of the courtyard, partly overlain by the temple altar (Plate 2). The stratigraphy and context of these latter structures suggest that they belong to buildings removed to make way for the Roman temple, Mau (1900: 272) and Eschebach and Eschebach (1995: 72, 78) suggesting that they were domestic in nature and pre-Sullan in date.

Below the eastern portico of the Roman sanctuary, Curti (2005: 75, fig. 14; 2008a: 53, fig. 6) uncovered cisterns, one of which contained votive offerings dating to the third century BC. Curti argues that these and a short stretch of a pappamonte wall point to a religious context, although they do not betray the actual structure of a temple. Building on earlier work by Coarelli (1998: 185-6) on Pompeian cults, Curti posits continuity of cult on the site and constructs an argument, largely on linguistic grounds, for a cult of the Samnite Mefitis. Although some kind of cult activity in this sector of the city in the centuries and decades before the establishment of the colony is certainly possible, it is difficult to attribute these votive deposits to a particular deity, even if, for Curti, Mefitis is 'la candidata ideale' (Curti, 2008a: 52), or to connect an early, fragmentary structure with the later temple of Venus. Curti concludes (2005: 74-5; 2008a: 53-6, fig. 7) that the first monumental sanctuary of Venus belonged to the period between 130 and $120 \mathrm{BC}$, when it replaced the postulated Mefitis sanctuary, and when work on the basilica and other public buildings was being conducted. This is a significant departure from the traditional attribution of the temple of Venus to the period immediately following the establishment of a Roman colony (Mau, 1900: 304-5; Mau, 1902: 124; Noack and Lehmann-Hartleben, 1936: 15; Adamo Muscettola, 1992: 77-8; Descoeudres, 1994: 27; Eschebach and Eschebach, 1995: 78; Zevi, 1996: 128-9; Zanker, 1998: 64-5; Coarelli et al., 2002: 86; Ling, 2005: 55). Without firm evidence or a discussion of stratigraphy to substantiate a second-century date for the sanctuary, however, Curti's proposed chronology remains hypothetical.

Admittedly, not much archaeological evidence has been presented by scholars favouring an early colonial date for the sanctuary of Venus, but the data recovered in our fieldwork now 

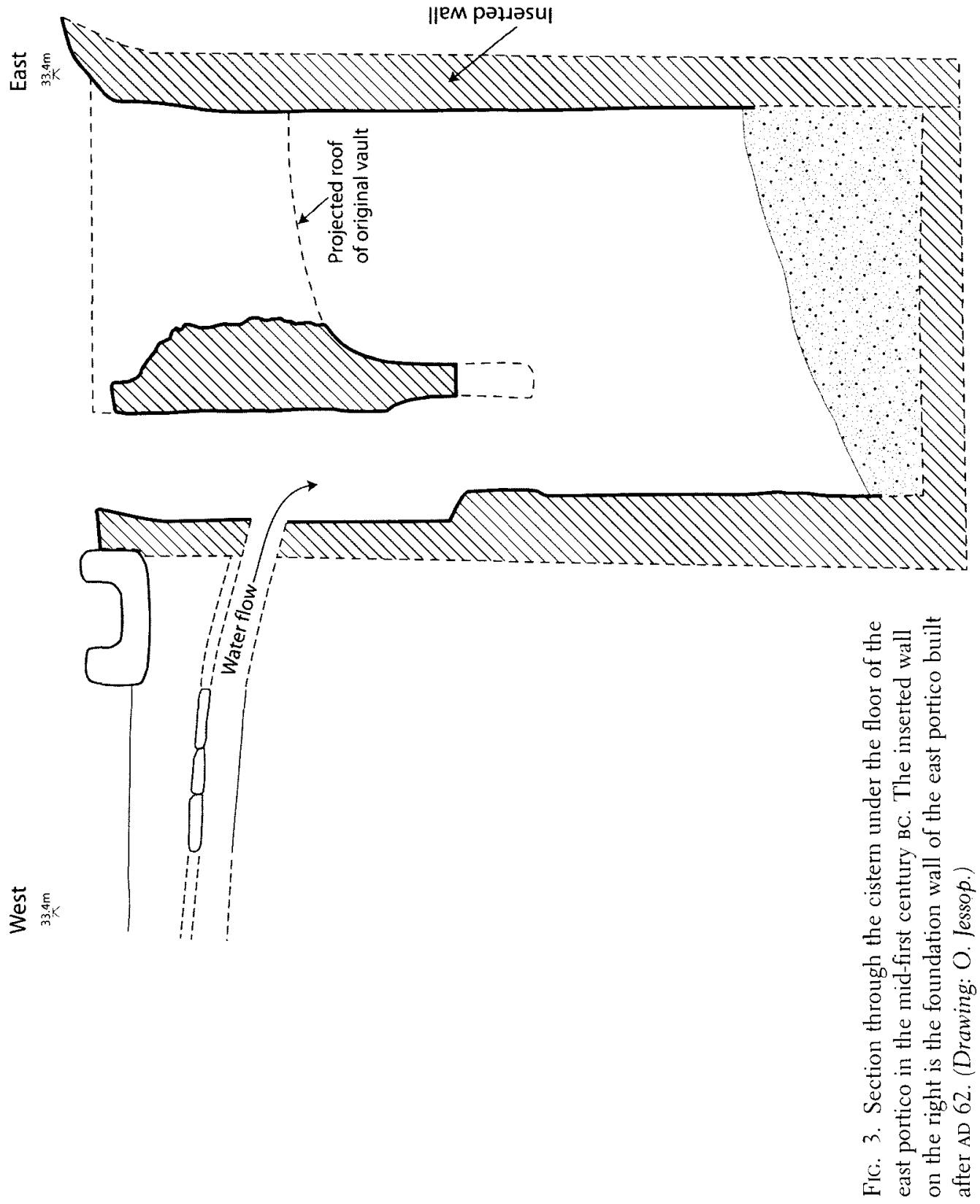
South

North

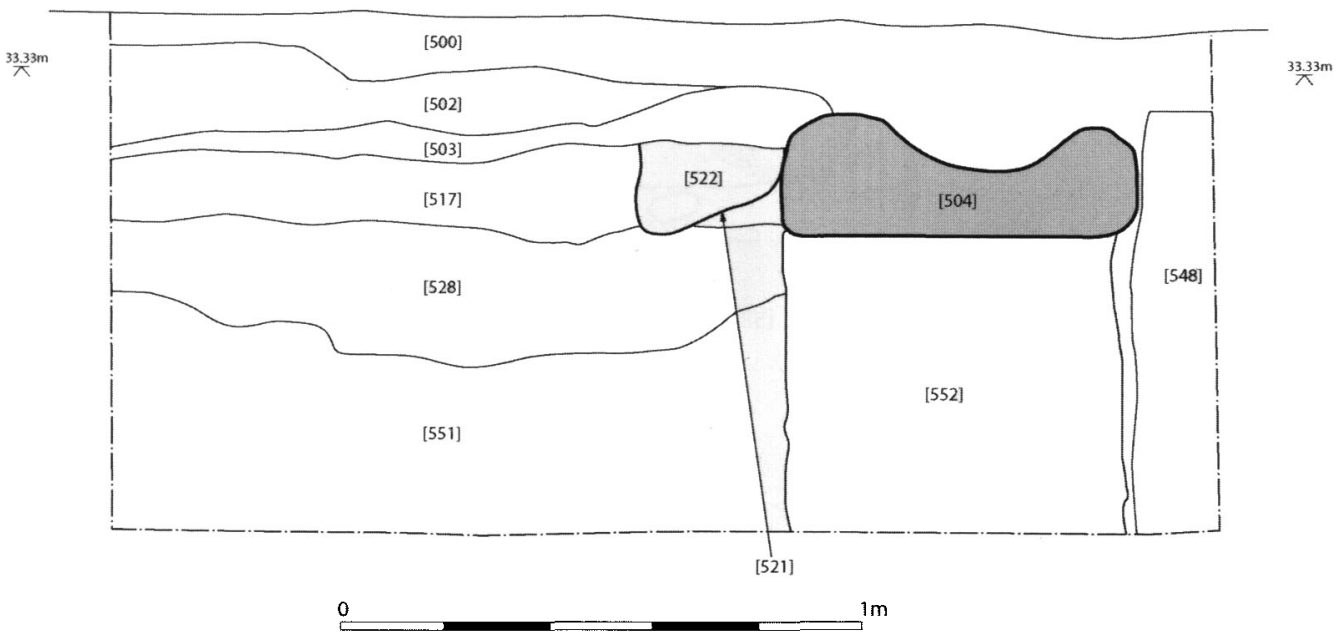

Trench 5

FIG. 4. Section through the western part of Trench 5 showing temple terrace deposits 551 and 528 and the late Augustan levelling deposit 517 overlain by mortar paving 503. To the east of the tuff water-channel (504), on its foundation wall (552), are the foundations under the stylobate of the north portico (548). (Drawing: O. Jessop.)

support this chronology. Large deposits of building debris, rubble and soil at least $1.5 \mathrm{~m}$ thick were brought in to create a level terrace for the new temple and its porticoes. The foundations of the buildings and the temple terrace deposits were part of the same phase of building and done in rapid sequence. Figures 4 and 5 show these deposits and structures in section; the appearance of the foundations and deposits upon excavation is illustrated in FIGURE 6. The terrace deposits also contained much domestic rubbish and pottery dating to the third and second centuries $\mathrm{BC}$ (FIG. 7). However, based on the latest pottery - sherds of Dressel 1 amphorae, south Spanish amphorae and Italian terra sigillata - , the terrace deposits appear to have been laid down around the mid-first century BC. ${ }^{2}$ Curti (2008a: 56) recognizes a period of activity in the sanctuary around the middle of the first century $\mathrm{BC}$, but he interprets this as a partial restructuring of the second-century Samnite sanctuary, rather than the first monumental phase, as we suggest.

That the first monumental sanctuary was constructed following Roman intervention in Pompeii might be indicated also by the presence of a particular group of artefacts: lead slingshot (Greep, 1987) (FIG. 8). Pompeii's participation in 91 BC in the so-called Social War against Rome resulted in Rome launching brutal campaigns against her Italian allies (Appian, Civil Wars 1.39, 50; Velleius Paterculus 2.16.2; Orosius, Histories Against the Pagans 5.18.22). Pompeii was subjected to a lengthy siege and taken in $89 \mathrm{BC}$ (Castren, 1975: 37-8, 49-50; Keaveney, 1987: $117-30,152-3)$. The pock-marked external surface of the northern city wall is testimony to

2 The ceramic analysis was conducted by Myles McCallum, St Mary's University, Halifax, Canada. 


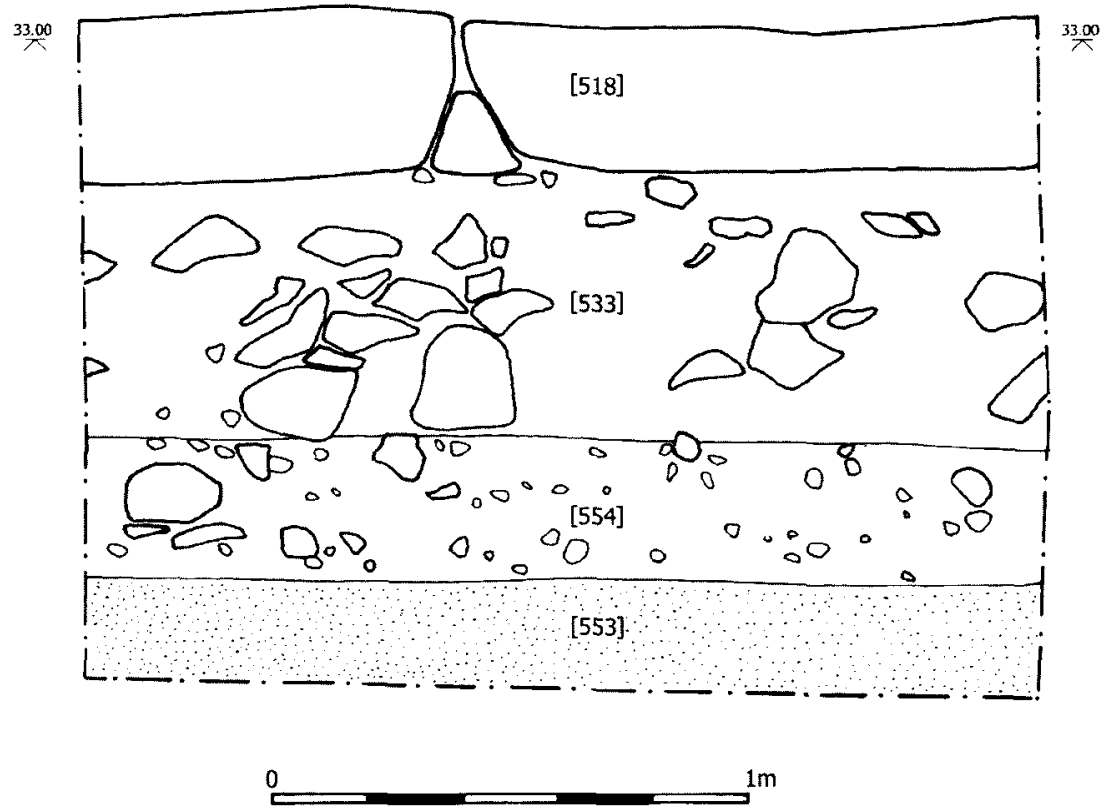

FIG. 5. Section through temple terrace deposits 553 and 554 on which the foundation wall (533) for the tuff water-channel (518) in front of the east portico rests. (Drawing: I. Willmott.)

the damage inflicted by Sulla's troops positioned outside the town. A clear destruction and demolition horizon inside the northern defences and a substantial amount of lead slingshot and stone balls fired by Sulla's artillery and slingers indicate that the houses inside that stretch of wall bore the brunt of the artillery attack (Jones and Robinson, 2004: 114-15, 123, fig. 9; D. Robinson, pers. comm.). Lead slingshot certainly was used elsewhere during the Social War, and it was employed later by both Caesar and Pompey in attacking and defending fortifications. ${ }^{3}$ The slingshot found at the temple of Venus was mixed in with the deposits of building rubble used to create the sanctuary terrace, perhaps pointing to the commencement of construction in the period after $89 \mathrm{BC}$. It is unclear whether the demolition debris at the temple might have come from the destruction of earlier buildings on that site or whether it was brought here from the clearing of the devastated properties in the northern sector of the city.

Also relevant to the dating of the sanctuary to the Roman period is its relationship with the Samnite city wall. The sanctuary of Venus was open on the south (PLATE 3), and this layout would have necessitated the removal of the city wall on the southern side of the precinct. Pompeii's fortifications appear to have been repaired after the Sullan siege under the supervision

3 Asculum: CIL IX 6086.i; see also CIL IX 6086.xxi, CIL II 4965. Caesar, Gallic War 2.7.10, 19, 24; 4.25; 7.81; 8.40; Civil War 1.27; 3.4, 46 . 
FIG. 6. View from the west of a section through the stylobate foundations of the north portico (left) and the rough foundations supporting the tuff gutter (middle) in front of the portico. To the right are deposits of rubble and debris used to create the temple terrace. (Photo: author.)

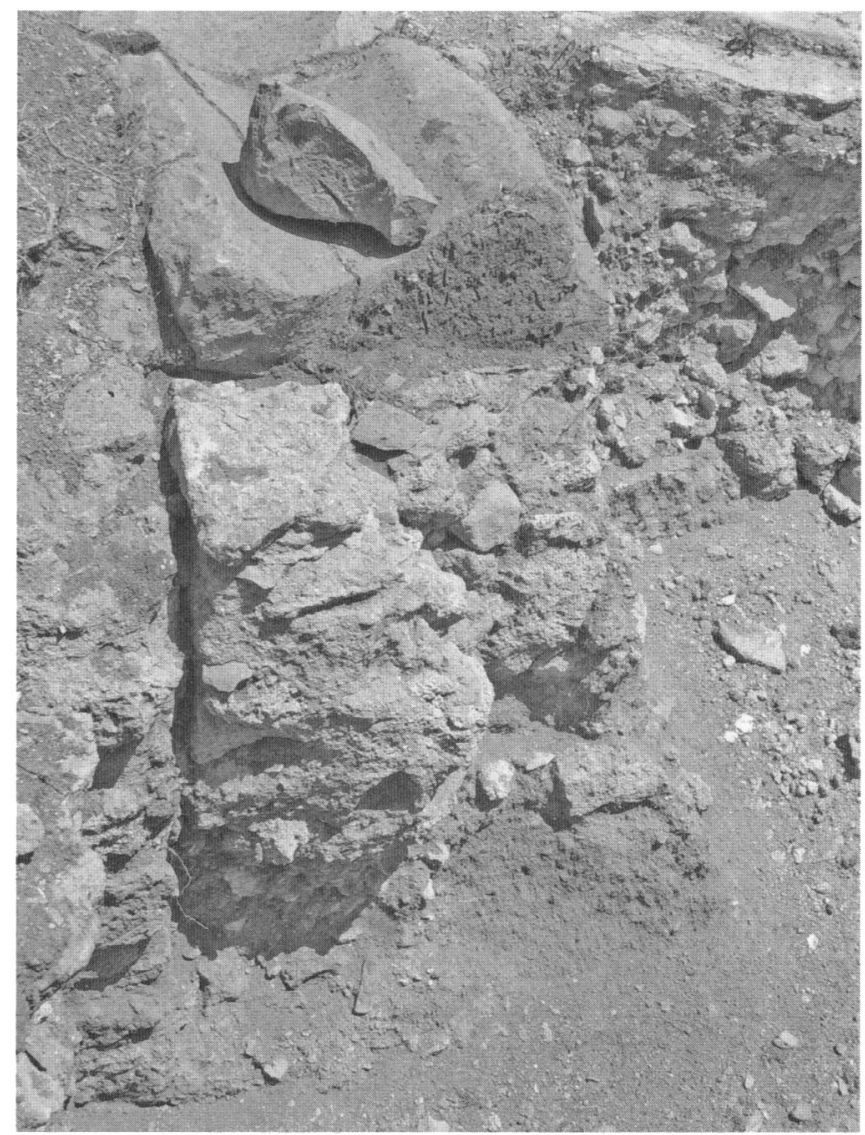

of two early colonial magistrates, as a surviving inscription (CIL X 937/ILS 5335) indicates; but the defences at some point were no longer needed and could be either dismantled or incorporated into public and private buildings, the latter being well represented in the Insula Occidentalis and immediately east of the sanctuary of Venus (Noack and Lehmann-Hartleben, 1936: 175-9; Richardson, 1988: 231-41; Eschebach and Eschebach, 1995: 83; Zevi, 1996: 130, 135; Zanker, 1998: 73-4, 143-5; Jacobelli, 2001: 34-6; Pappalardo and Aoyagi, 2006: $22-5$ ). Also in the northern and eastern parts of the town the fortifications had become largely superfluous fairly soon after the establishment of the colony. Some time before $50 \mathrm{BC}$ the House of the Vestals in Insula VI.l had encroached on the town's defences, and the earth rampart adjacent to the city wall had been removed almost completely (Jones and Robinson, 2004: 115). In $70 \mathrm{BC}$ the amphitheatre was constructed in the southeast sector of the city, making use of a now redundant stretch of the old city wall as support (Richardson, 1988: 134-8; Eschebach and Eschebach, 1995: 79). Fausto Zevi (1996: 129) argued that the most probable time for the decommissioning of the city walls would have been after the defeat of Spartacus in the Third Servile War (73-71 BC) and perhaps not until $70 \mathrm{BC}$, when the first census of the colony took place. 


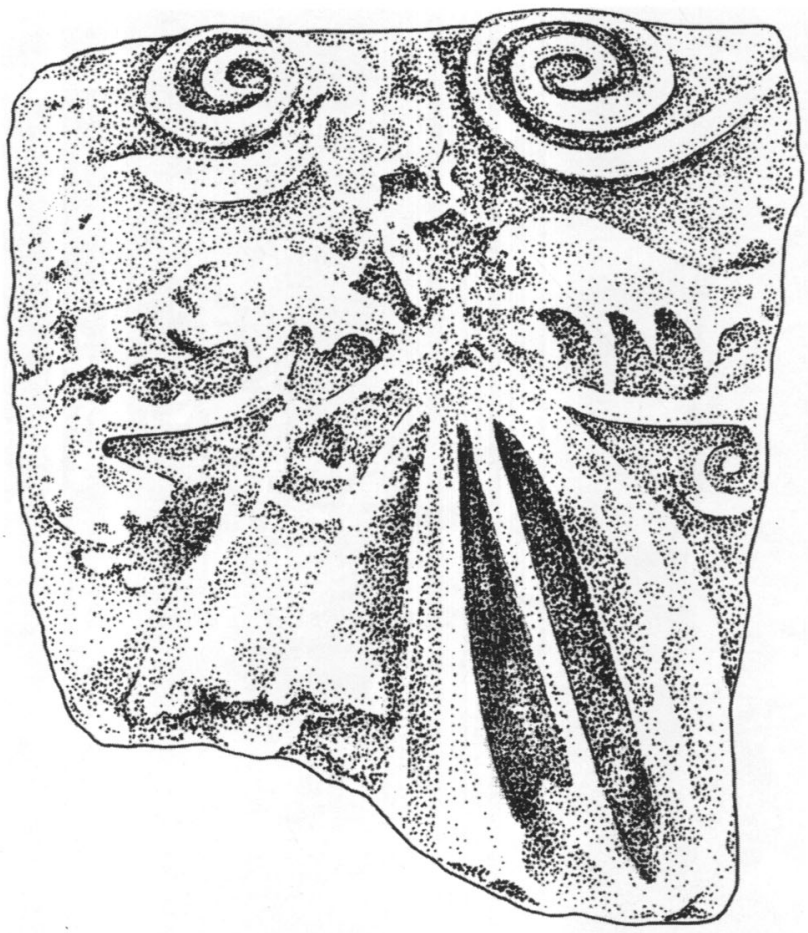

FIG. 7. Finds from the temple terrace deposits: painted terracotta architectural mouldings (left), terracotta loom weights (right). (Drawing: J. Willmott.)

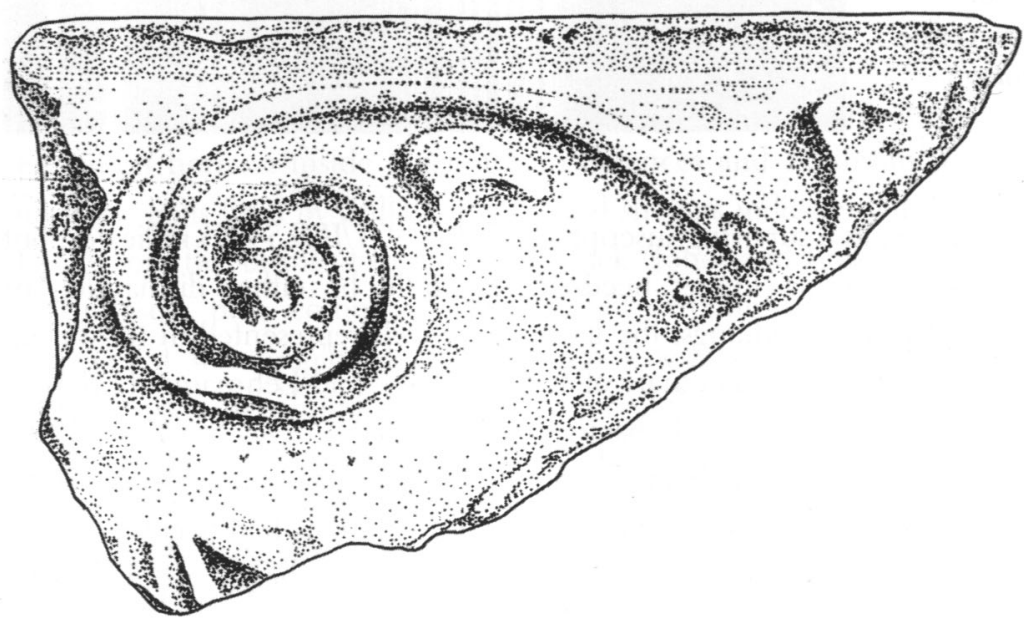

0 $5 \mathrm{~cm}$ 

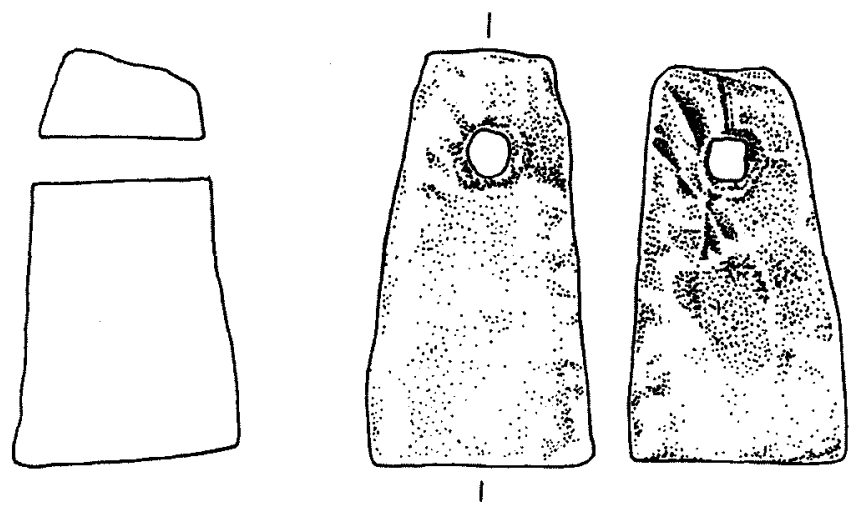

0 $5 \mathrm{~cm}$
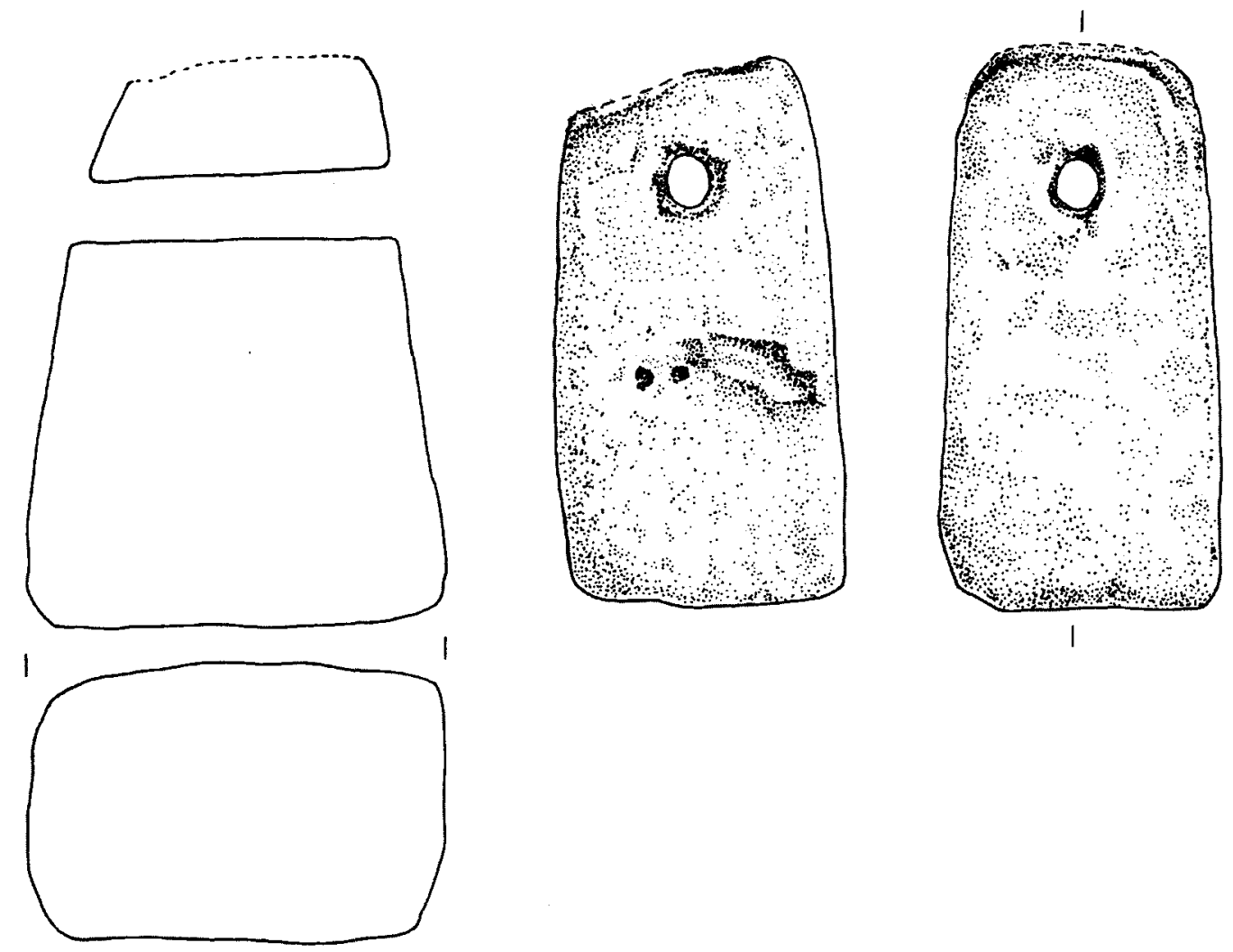


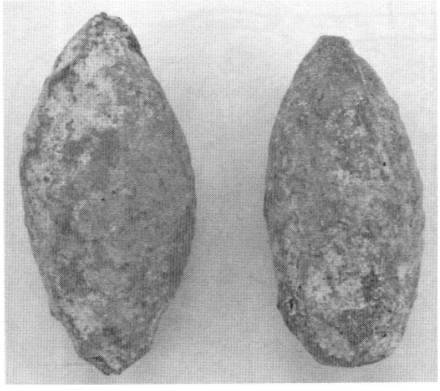

FIG. 8. Lead slingshot weighing between 52 and $57 \mathrm{~g}$ found in the temple terrace deposits. (Drawing: J. Willmott.)
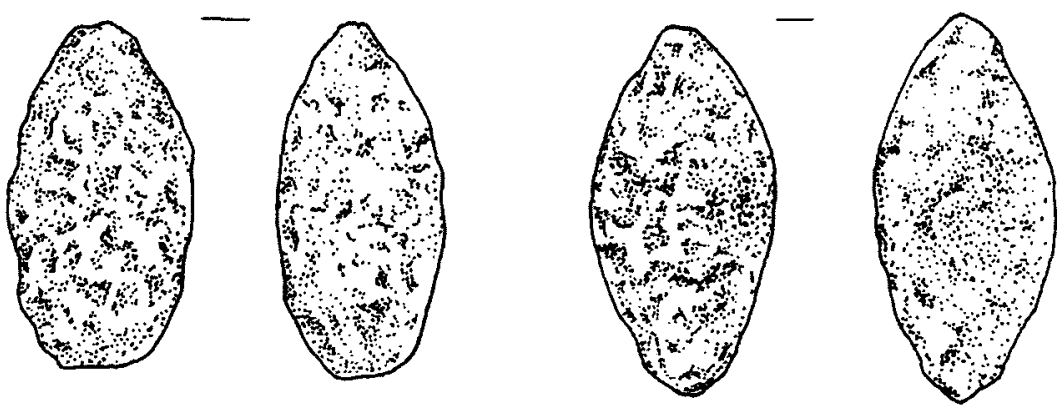

0

$5 \mathrm{~cm}$

The temple terrace deposits and the foundations of the sanctuary buildings are all part of the same coherent building phase dating to the same time. After evaluating the stratigraphic, artefactual and architectural evidence for the chronology of the site, the temple appears to have been a creation of the Roman colonists, although building it cannot have been their first priority in the years immediately after $80 \mathrm{BC}$.

\section{EVIDENCE FOR THE TEMPLE GROVE OF VENUS}

Although Jashemski (1979: 157) and Curti (2008a: 58, n. 26) both doubted the existence of a temple grove at the sanctuary of Venus, we now know with certainty that the precinct was landscaped. We uncovered planting pits for trees at a maximum depth of $50-60 \mathrm{~cm}$ below the stone gutter in front of the porticoes on the north and east sides; the west side could not be investigated, but there is no doubt that a row of pits in front of the west portico would have mirrored those in front of the east portico. These trees were dug into the rubble with the soil deposited on the slope for the temple terrace (FIGS 9 and 10). This stratigraphic situation and the fragments of Italian terra sigillata in the fill of the planting pits indicate that the grove was contemporary with the creation of the temple terrace. Trees were planted parallel to the colonnades on the north, west and east sides of the sanctuary, the latter two rows apparently stopping level with the front end of the temple on the south. 


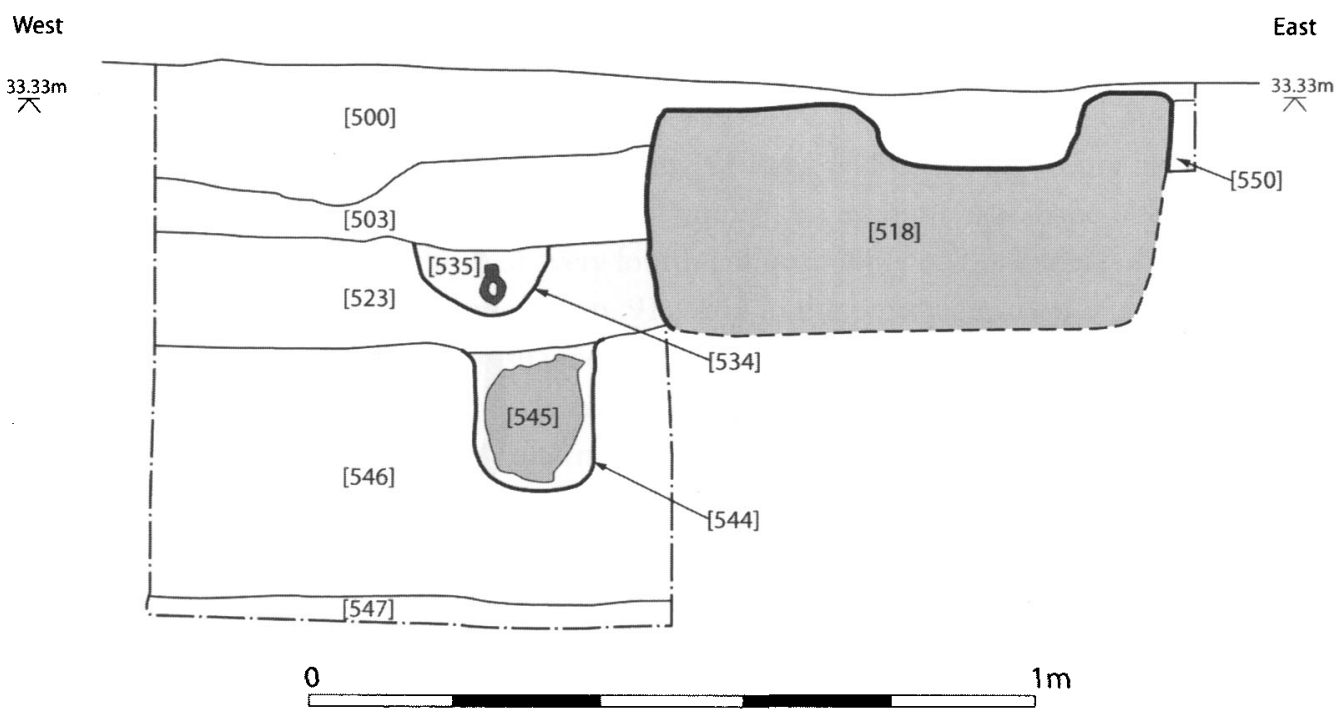

\section{Trench 5}

FIG. 9. Section through the eastern part of Trench 5 showing temple terrace deposits 547 and 546 and planting pit 544, with an in situ terracotta plant pot (545) from the temple grove. The late Augustan levelling deposit 523 and a lead water-pipe (543/535) are overlain by mortar paving 503. To the east of the tuff water-channel (518) are the foundations under the stylobate of the east portico (550). (Drawing: O. Jessop.)

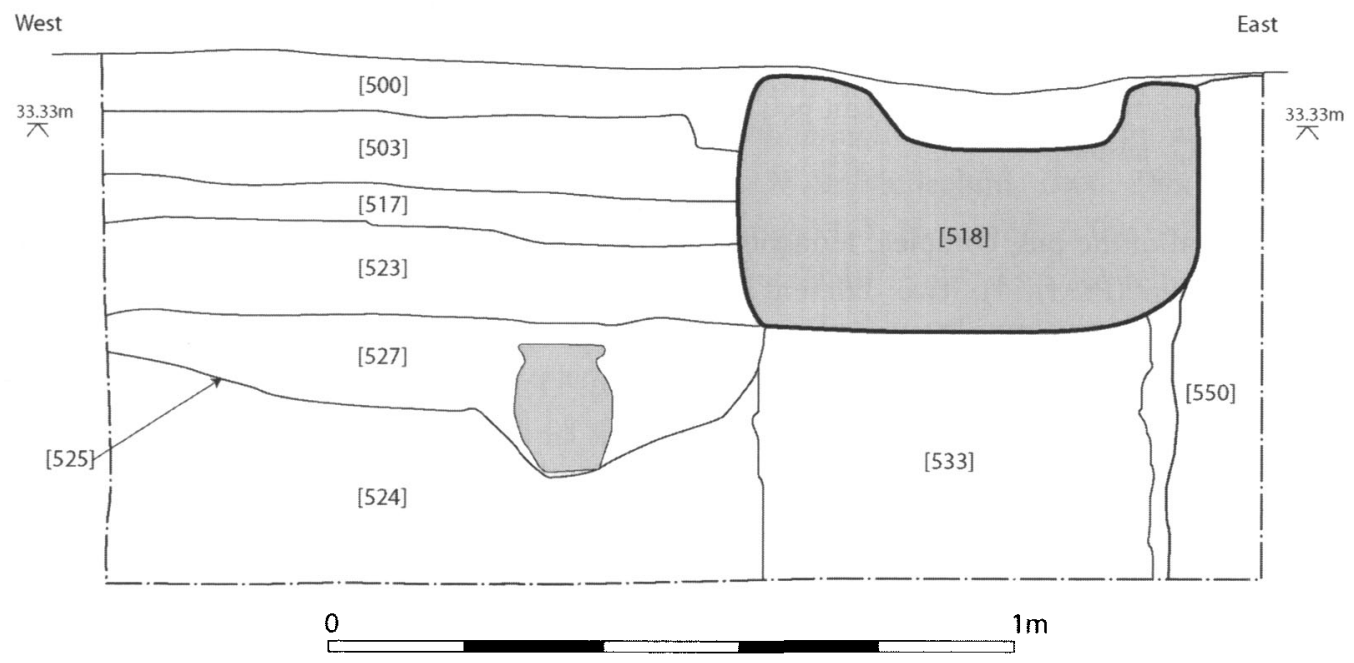

\section{Trench 5}

FIG. 10. Section through the courtyard deposits adjacent to the east portico in 'Trench 5 , showing a temple terrace deposit (524) and a planting pit (527) containing an in situ terracotta plant pot from the temple grove. The late Augustan levelling deposits (523 and 517) and the associated mortar paving layer (503) are overlain by modem topsoil (500). To the right is the tuff water-channel (518) on its foundation wall (533) in front of the east portico (550). (Drawing: O. Jessop.) 

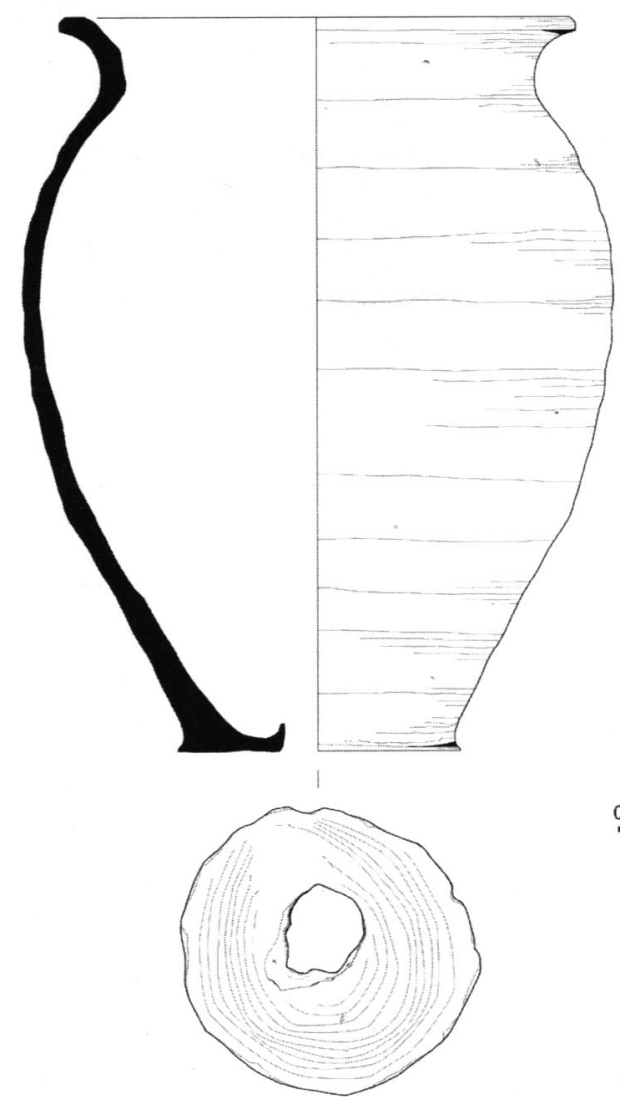
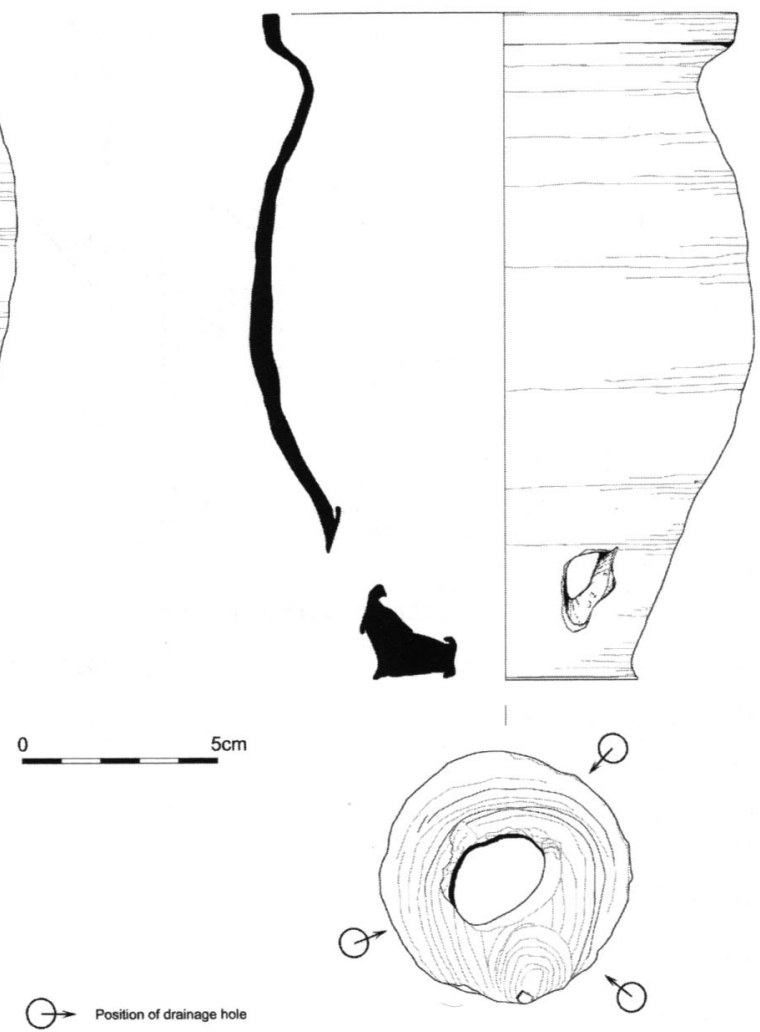

FIG. 11. Two types of terracotta plant pots from the sacred grove of the mid-first century BC.

(Drawing: O. Jessop.)

In several of the pits, complete terracotta pots in which young plants had been started were buried in situ (Plate 4). Two different types of containers are represented: pots with four holes in the lower walls and bottom of the vessel (Type A, 16-17 cm in height), and pots with one hole in the bottom (Type B, $19 \mathrm{~cm}$ in height) (FIG. 11). Plant pots are known from domestic gardens in Pompeii and elsewhere, but they were thus far unknown in conjunction with a sanctuary and in such an early context (Messineo, 1984; Jashemski, 1992; Desbat, 1997; Barat and Morize, 1999; Carroll, 2003: 88-92; Macaulay-Lewis, 2006). Cato (On Agriculture 51-2, 133) and Pliny (Natural History 17.21.97-8, 17.11.64) refer to the use of terracotta containers with holes for propagating and air-layering trees and shrubs, the branch taking root in the pot and, once removed from the tree, being brought to its ultimate garden destination in a convenient container.

The trees were planted at regular intervals of $0.9-1.0 \mathrm{~m}$, probably echoing the rhythms of the portico columns; with one tree in front of each column and one in between, an intercolumniation of roughly $2 \mathrm{~m}$ can be reconstructed. This close relationship between vegetation and portico columns is also evident in the context of domestic architecture in the late first 
century $\mathrm{BC}$ and first century $\mathrm{AD}$, from Oplontis and Stabiae in Campania to Prima Porta near Rome (Jashemski, 1979: 293-6, figs 443-6, 464; Jashemski, 1981: 43-6, figs 3 l-4; Jashemski, 1993: 294-5, plan 131; Barbet and Miniero, 1999: 53, figs 53, 73, 112; Liljenstolpe and Klynne, 1997-8: 128-35, figs 5-9). The pairing of trees and columns occurs also in public architecture. The Augustan Palestra Grande in Pompeii, for example, has plane trees at intervals of about $9 \mathrm{~m}$, with one tree in front of every fourth column of the colonnades (Jashemski, 1979: 160-1, fig. 246; Jashemski, 1993: plan on p. 91). And in the peristyle garden of a building near the so-called Tempio Rotondo in Ostia, ceramic planting pots in situ were placed before each column of the surrounding portico (Messineo, 1984: 71, fig. 16).

The regular pattern of planting, alternating with two different types of pots and with pits containing no pot, may reflect tall vegetation alternating with shorter vegetation, or it may simply imply a sequence of trees and shrubs that required propagation in ceramic pots and those that did not need containers to develop (FIG. 12). The sequence suggests three possible different types of trees or bushes, but without the preservation of organic remains we cannot say for certain what species of plants grew here. ${ }^{+}$It is possible that some of the trees were laurel, as branches of this tree were used in triumphal processions and to sprinkle water on objects to be purified, the latter use being perhaps particularly relevant in a sanctuary (Pliny, Natural History 15.39.127-32, 15.40.133-8; Juvenal, Satires 2.15). Myrtle, with its dark berries and white blossoms, was particularly sacred to Venus, and it is possible that it was also planted here (Pliny, Natural History 12.2.3, 15.36.12; Virgil, Eclogues 7.61-2; Ovid, Fasti 4.141-4; Pausanias, Guide to Greece 6.24.7). Like laurel, the 'myrtle of Venus Victrix' was worn as a wreath in celebrations of an ovation or triumph, and sprigs of the tree when burned had purifying properties (Pliny, Natural History 15.38.125, 15.36.120; Cato, De Re Rustica 8.2; Virgil, Georgics 1.28). A third possibility for some of the plants in the grove of Venus is the rose, a flowering shrub attested in the first century AD in public architecture and parks, in particular at the Templum Pacis in Rome (S. Rizzo, 2001: 238-9; Meneghini, 2006: 158-9, fig. 19; Meneghini and Santangeli Valenzani, 2007: 61-70, figs 54-5; Newsome, 2009: 68). Pausanias (Guide to Greece 6.24.7) and Pliny (Natural History 21.10.15-17, 13.6.26) tell us that the rose was connected to Venus and was valued particularly highly in Campania.

Cato (On Agriculture 51-2) included the laurel and the myrtle amongst those types of vegetation that could be propagated by air-layering in pots, although Pliny (Natural History 17.11.60-2) said that the laurel could be grown from seed, from slips or by layering, and that the myrtle in Campania was grown from berries, unlike at Rome where it was layered. The rose generally was propagated by grafting or growing from slips, so that ceramic starter pots might not have been necessary (Pliny, Natural History 21.10.20-1).' As a working hypothesis, therefore, we might reconstruct the plantings in the sanctuary as consisting of laurels and myrtles,

4 The environmental analysis of soil samples was carried out by Glynis Jones, University of Sheffield.

5 The roses at the Templum Pacis were planted in halved amphorae, but these may have been transport containers, rather than pots used to propagate the shrubs. 


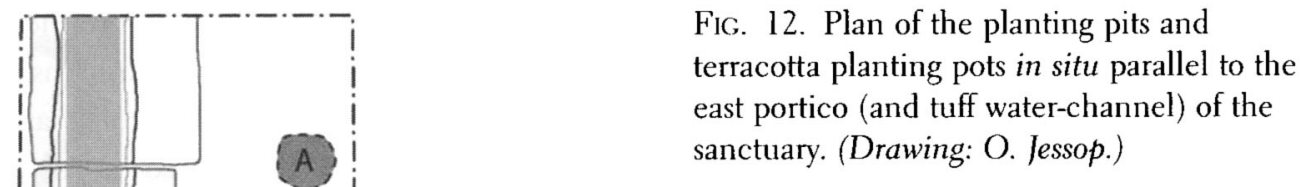

FIG. 12. Plan of the planting pits and east portico (and tuff water-channel) of the sanctuary. (Drawing: O. Jessop.)

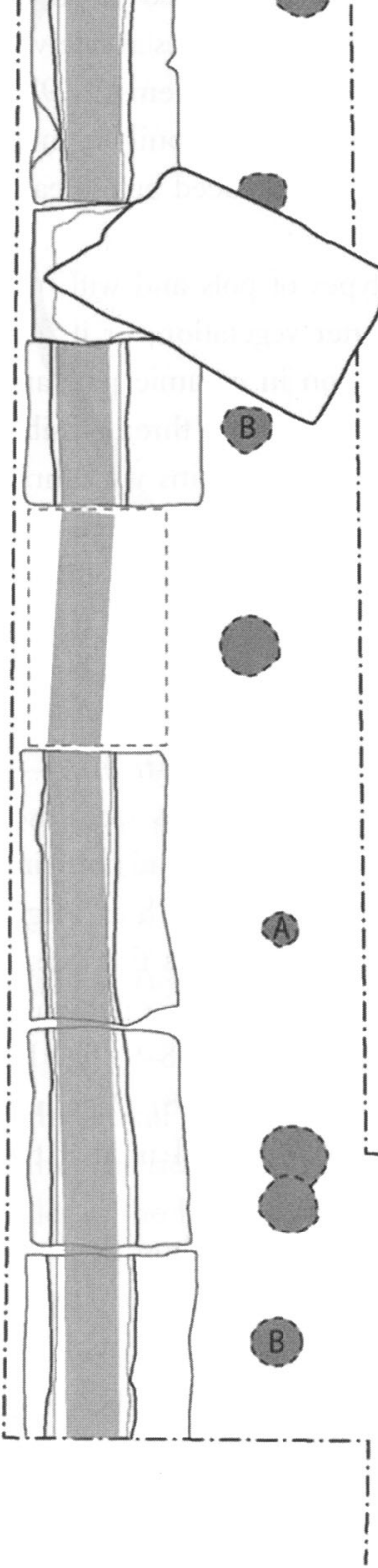

Planting pot type $\mathrm{A}$

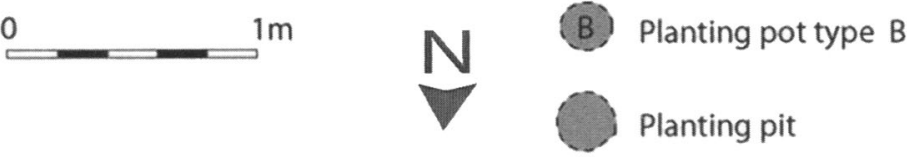



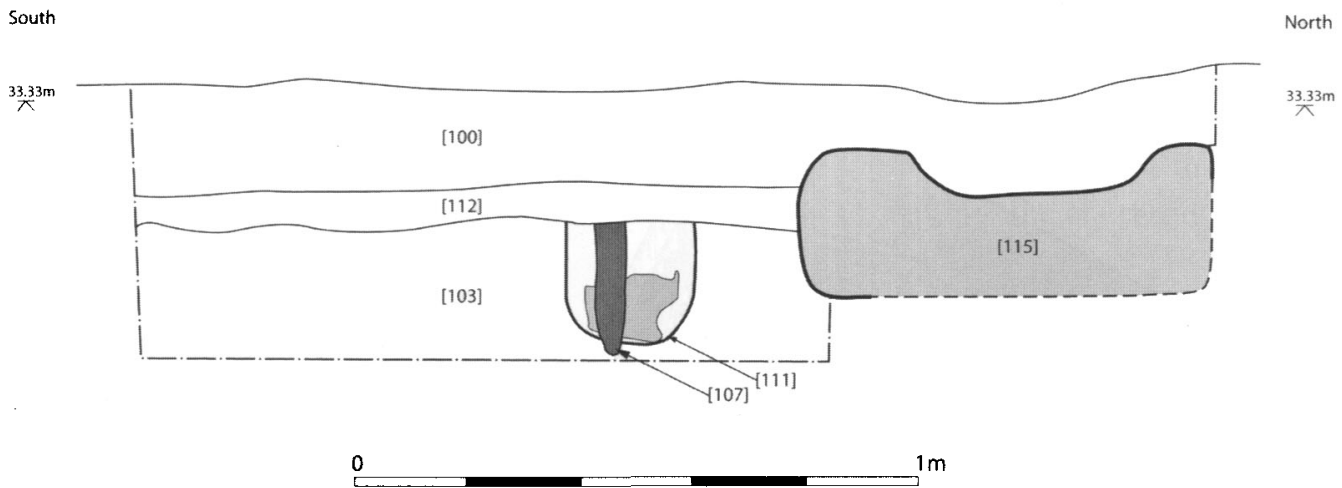

Trench 3

FIG. 13. Section in Trench 3 through a temple terrace deposit (103) of the mid-first century BC into which a planting pit (111) with a terracotta plant pot (here lying on its side) was inserted in front of the north portico. A wooden support for the growing vegetation (107) was driven through the plant pot. Deposit 112 is a levelling layer sealing the abandoned grove in the early first century AD. On the right is the tuff water-channel (115) in front of the north portico. (Drawing: O. Jessop.)

grown and transported in ceramic pots, and rose bushes whose root-balls were planted directly in the ground.

It is likely that the plantings and layout in this porticus triplex constituted a nemus: a grove created or manipulated by human action and furnished with cult buildings and images. Unfortunately, due to later alterations and the rebuilding of the sanctuary, it is entirely unclear what images and votives may have stood in the nemus at this time. The grove of Venus was clearly not a lucus, the term originally meaning a 'clearing' within the woods and later referring to a grove that was created and inhabited by divine spirits and left in a natural state (Stara-Tedde, 1905; Coarelli, 1993: 47-8; Scheid, 1993: 19).

Temple groves required the attention of gardeners, but until now only a few written references to temple gardeners, such as those at the sanctuary of Athena Nikephoros at Pergamon or at the sanctuary of Dea Dia outside Rome, provided any information on their activities (Polybius 16.1.6, 18.6; Strabo, Geography 13.4.2; Broise and Scheid, 1993; Beard, North and Price, 1998: II, 87-8). It is apparent in this context how exceptional and valuable the archaeological traces of garden work at the temple of Venus are. There is evidence, in the form of intercutting planting pits, for trees that failed to flourish being replaced in the same spot, and traces of wooden stakes driven into the ground indicate the use of supports for growing trees (FIG. 13). The plant pots themselves show that plant nurseries existed. As the bone and shell fertilizer in the soil in the pots indicates, gardeners and plant specialists in the nursery did what they could to ensure that the shoots and saplings destined for the temple for landscaping purposes would thrive. ${ }^{6}$ It is unknown

6 The animal bone analysis was conducted by Sarah Viner, University of Sheffield. 


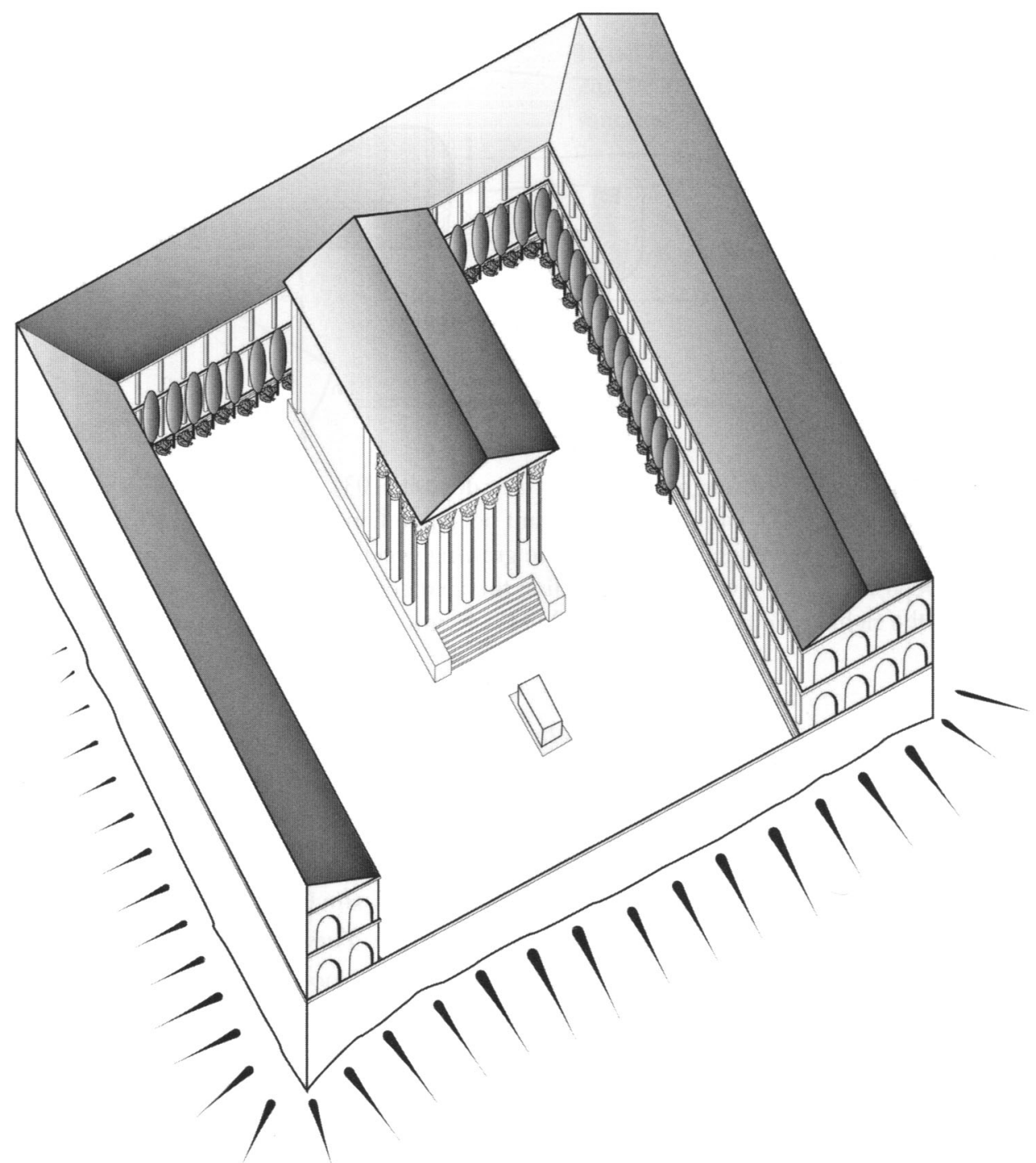

FIG. 14. Reconstruction of the sanctuary of Venus and its sacred grove in the mid-first century вС. (Drawing: O. Jessop.)

where such facilities were located, but they might have existed on the floodplain of the Sarno, since there is later evidence in Pompeian domestic gardens for plants having been raised in a growing medium of alluvial soil (Robinson, 2007). Marine or alluvial clays appear to have been used in the manufacture of some of the planting pots too, so perhaps the kilns for the plant pots and the nurseries for the fledgling trees were in similar locations near the river.

The vegetation in the sanctuary of Venus acted as a device to highlight the temple visually, so that in approaching the temple from the front (south) the viewer would see the building framed by trees and bushes on three sides; the trees, in turn, had the columns of the colonnades behind them as a backdrop (FIG. 14). This effect would be the same whether one entered the sanctuary 
from the south, by a possible access route from the valley floor, or from the northeast gate, moving through the eastern portico to its southern end and then turning into the courtyard to face the temple, a route that can be demonstrated archaeologically (see below). By the same token, the experience of passing from the public and secular to the private and sacred might have been heightened by having to cross through a row of trees to step into the courtyard from the surrounding porticoes.

\section{Porticus triplex and The grove in Roman SaCred architecture}

The trees at the sanctuary of Venus were arranged around three sides of the temple, the grove itself being contained by a porticus triplex. A sacred grove laid out in tripartite form, but without the porticoes enclosing it, can be found already in the third century $\mathrm{BC}$ in Athens. Here, at the temple of Hephaistos on the Colonus hill, rows of planting pits were dug into the natural rock, each pit containing a ceramic planter for a tree or bush next to each of the peripteral columns of the temple (Thompson, 1937). In the mid-second century BC, a tripartite grove appears together with a porticus triplex as an integral design element in temple architecture in Italy. Excavations at the sanctuary of Juno on the rim of a volcanic lake at Gabii revealed rows of holes cut into the rock for trees and arranged in an open courtyard on three sides of the temple, the trees in turn being enclosed by porticoes (Lauter, 1968-9; Coarelli, 1993: 48-51; Almagro-Gorbea, 1982). Too little is known about other central Italian terrace sanctuaries of the second and first centuries $\mathrm{BC}$ to determine what planting design was followed, although it is fairly certain that their courtyards harboured gardens or groves. The terraced sanctuary of Diana at Aricia above Lake Nemi had a sacred grove, and Roman mythology and legend has Aeneas and the Rex Nemorensis plucking the 'golden bough' from a tree in it (Strabo, Geography 5.3.12, 5.1.2; Virgil, Aeneid 6.124-211; Suetonius, Caligula 35; Pausanias, Guide to Greece 2.27.4; Coarelli, 1987b: 165-85; Ampolo, 1993: 161-3; Ghini, 1993; Guldager Bilde and Moltesen, 1997; Ghini, 2000; Guldager Bilde and Moltesen, 2002). At the sanctuary of Hercules Victor in Tivoli, a deposit of loam and planting pits in the precinct point to sanctuary landscaping (Coarelli, 1987b: 89). The sanctuary of Fortuna Primigenia at Praeneste also may have been planted on at least one terrace, as the fairly recent discovery during clean-up work of a series of pits dug into the rock on the lower terrace indicates.

The design of formal plantings in a porticus triplex, seen at the Pompeian temple of Venus, was one of some longevity. By the Augustan period, this layout had become firmly established in sanctuary architecture throughout Italy and the Mediterranean. The victory monument at Nikopolis, built between 29 and $27 \mathrm{BC}$ to celebrate the defeat of Antony and Cleopatra at Actium in $31 \mathrm{BC}$ by Octavian (later Augustus), for example, was laid out as a porticus triplex with an altar in the centre of the courtyard. The precinct was open at one end, with a view

\footnotetext{
7 I thank Sandra Gatti, of Palestrina, for this information.
} 
down the slope to the site of the battle. The recent discovery of ceramic plant pots inserted in the ground parallel to all three porticoes proves beyond doubt that the courtyard was planted (Zachos, 2003). Octavian himself must have chosen the trees for his precinct sacred to Mars, Neptune and Apollo, and it is likely that they were laurels, as these were particularly sacred to his patron god Apollo; laurels were also present in the grove surrounding the gymnasium and stadium at Nikopolis (Strabo, Geography 7.7.6). The laurel became the personal emblem of Augustus after the Senate planted one on either side of the door of his house in Rome in 27 BC (Augustus, Res Gestae 34).

This tree played an important role again at his wife's villa at Prima Porta, north of Rome. On a large area of level ground, the so-called garden terrace, to the east of the villa and open to and overlooking the valley, the Swedish excavators uncovered evidence for a porticus as well as many terracotta planting pots, perhaps once containing the laurel trees from which Augustus and later Julio-Claudian emperors cut branches for their triumphal wreaths (Liljenstolpe and Klynne, 1997-8: 135-47). If this porticus triplex and laurel grove were designed intentionally to reflect the layout of a sacred precinct and allude to the divine sanction of the Julian family, as Klynne (2005: 171-4) has suggested, then the combination of a tripartite grove and surrounding porticoes was well enough established as a form of temple landscaping to be recognizable as such, even in a secular context such as Livia's villa. Outside Italy, the porticus triplex and grove were still employed in temple architecture decades later. A Flavian-period sanctuary at Munigua in Spain, for example, was designed with a planted upper terrace, although the grove was located either side of the temple, rather than enveloping it on three sides (Grünhagen, 1959; Hauschild, 1992; Coarelli, 1987a; Strocka, 2005: 165, fig. 12).

Porticoes surrounding public parks and gardens of course played an extremely important role in Rome itself, the earliest of all being the porticus of Pompey dedicated in $52 \mathrm{BC}$ (Gleason, 1994). The square, planted with rows of plane trees, was surrounded by colonnades on all four sides and stood adjacent to a theatre and the temple of Venus Victrix. Over a century later, the Templum Pacis was built by Vespasian with four porticoes (later reduced to three) surrounding formal plantings, water basins and plundered art to celebrate the conquest of Judaea (Anderson, 1982; S. Rizzo, 2001: 238-9; Meneghini, 2006: 158-9, fig. 19; Meneghini and Santangeli Valenzani, 2007: 61-70, figs 54-5; Pollard, 2009). Unlike the terraced sanctuaries discussed above, however, such urban complexes were not meant to open up with panoramic views and embrace the surrounding landscape; instead, the porticoes, enclosing the courtyard on all sides, create a rather more introverted complex of gardens, art displays and opportunities for relaxation and public interaction. The design of a planted courtyard within porticoes continued to be employed in temple architecture as late as the third century, but here too these later sacred gardens and groves often were surrounded on all sides by colonnades, with their rows of trees flanking, rather than framing, the temple. Both the so-called 'east temple' in 'Thuburbo Maius and the temple of Elagabal on the Palatine in Rome, for example, focus inwards on the plantings and architecture in a precinct shut off from the surrounding area (Jashemski, 1995: 573, figs 13-14; Andreae, 1957; Villedieu, 200 Ia; Villedieu, 2001b; G. Rizzo, 2001). 


\section{Changes to the temple grove in the early IMPerial period}

In the early first century $\mathrm{AD}$, the temple of Venus and its colonnades were refurbished; the orientation of the buildings and at least their foundations, however, remained in use. In an architectural appraisal of the sanctuary, Markus Wolf (2004: 193-4) concluded that the sanctuary buildings had been rebuilt in marble and completed before $\mathrm{AD} 30$ on exactly the same alignment and on the same scale as the earlier tuff buildings. A study by Luciana Jacobelli and Patrizio Pensabene (1995-6: 53, cat. nos. 1-12, 18-44) of the Corinthian column capitals, bases and cornices recovered in 1900 placed the new refurbishment in Luna (modem Carrara) marble roughly in the years between $20 \mathrm{BC}$ and $\mathrm{AD} 30$.

At the same time, the sacred grove went out of use or was destroyed, although we have no idea why. The builders dumped a levelling layer of soil on the remains of the earlier grove, as can be seen in Figures 4, 9 and 10 (contexts 517 and 523). It contained painted plaster from walls and columns, including various pieces with graffiti (FIG. 15), as well as tile and pottery. Diagnostic pottery from this deposit, and particularly part of an Italian terra sigillata bowl of Conspectus Form 18.2 (Kenrick, 1990: 82-3), suggests a date between the late first century BC and the Tiberian period. The levelling layer also contained numerous offcuts and chips of white marble left behind by stonemasons and sculptors. Petrographic and stable isotope analyses demonstrate that the source of the marble was the quarries at Luna, the same as that for the

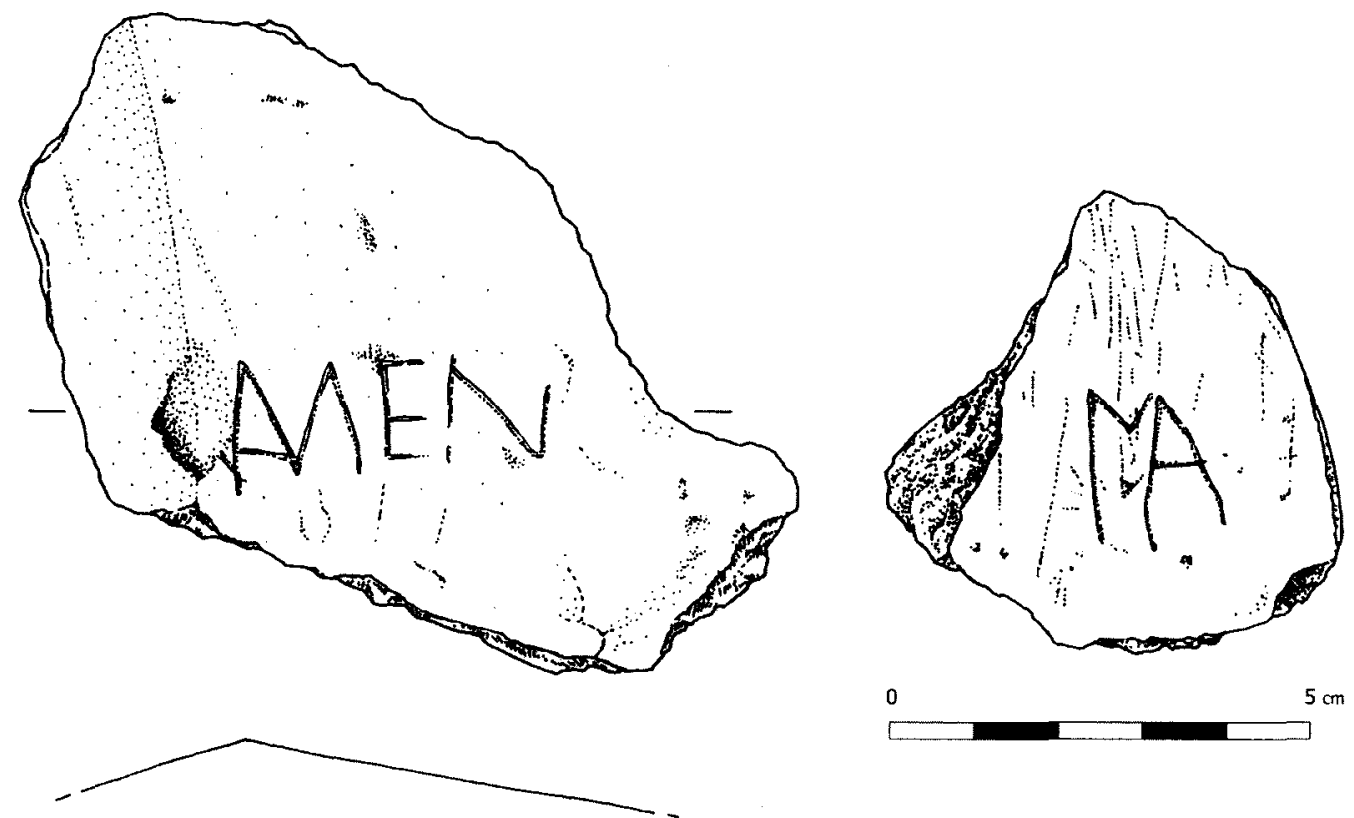

FIG. 15. White plaster from walls and columns found in the levelling deposits of the early first century AD. Graffiti on these fragments include MEN (left) and MA (right). (Drawing: J. Willmott.) 


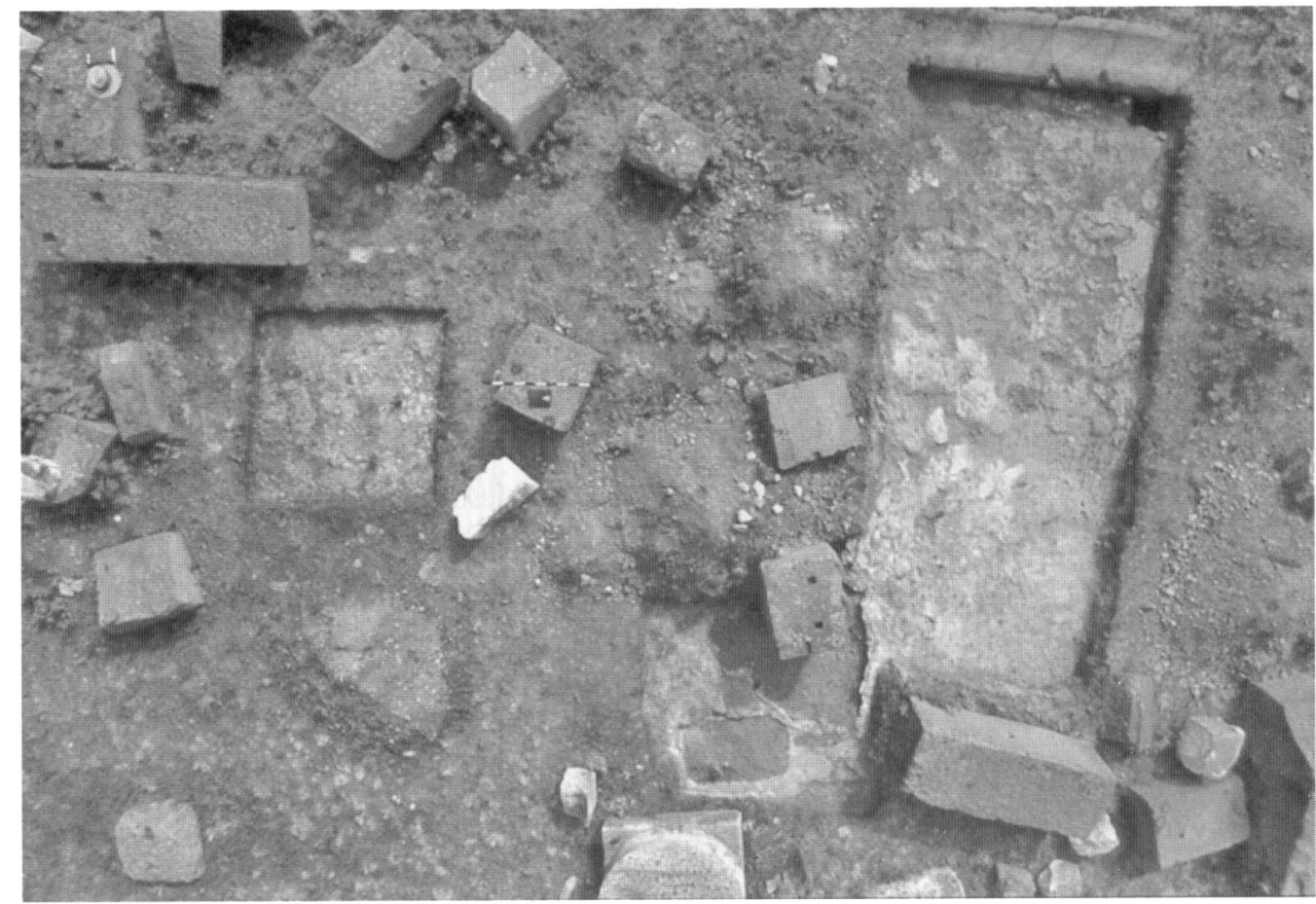

FIC. 16. View from above during excavation of mortar paving 503, with the east portico at the top of the image. (Photo: author.)

decoration of the temple's superstructure studied by Jacobelli and Pensabene (Carroll et al., 2008).

The levelling deposit in the courtyard was covered with a paving of greyish white mortar several centimetres thick, and there was no evidence that this was a sort of underlay for stone paving slabs, even if a mortar floor might seem a bit primitive for a marble-clad temple (FIG. 16). The mortar layer (context 503) clearly seals the levelling deposits in the section drawings in Figures 4, 9 and 10. The temple courtyard cannot have had a grove in this phase, at least with trees planted in the ground as they once had been. Of course, some public parks and sacred precincts at Rome, like the temple to the deified Julius Caesar in the forum and the Palatine sanctuary of Elagabal, had paved courtyards into which vegetation in masonry planters was inserted (Andreae, 1957; G. Rizzo, 2001; Villedieu, 2001a; Villedieu, $200 \mathrm{lb}$ ). Unlike these precincts, however, there is no evidence in the courtyard of the temple of Venus for the insertion of plants into the mortar paving, so perhaps the idea of trees or shrubs in containers above ground should be considered. Particularly relevant here is a wallpainting from the oecus in the House of the Wedding of Hercules that shows a building with Corinthian columns, almost certainly the temple of Venus, with cult statues of the goddess, Eros and Priapus (VII.9.47) (PPM vol. 7, Regio VII, parte II (1997), 373-5, fig. 32). The most interesting of the offerings carried and led into the sanctuary by temple personnel in this scene is a foliated tree in a square container, clearly indicating that trees could be dedicated 


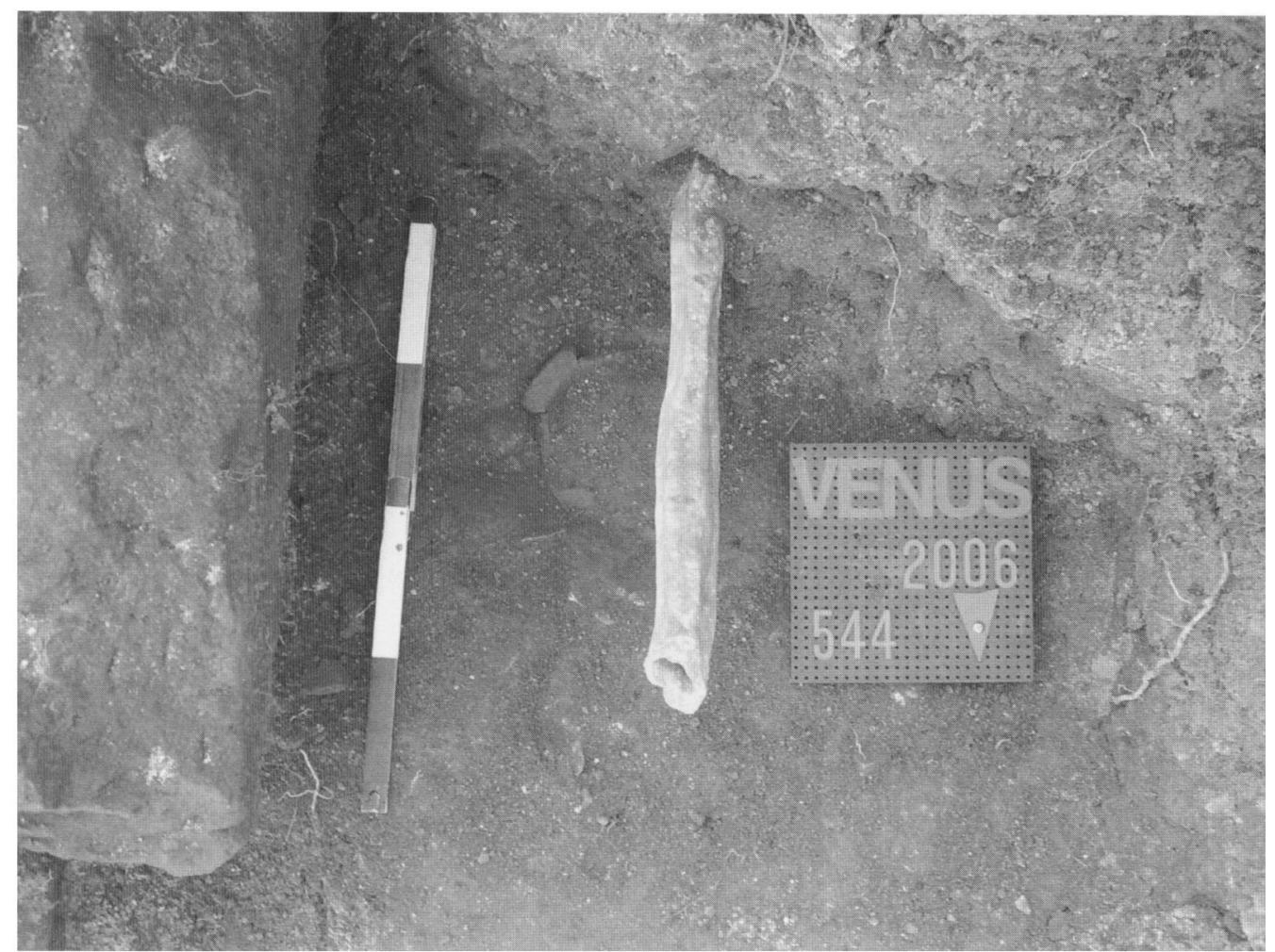

FIC. 17. Length of lead pipe under the mortar paving (here a greyish layer). Note the plant pot in situ beneath the Augustan levelling layer, just below the lead pipe. To the left is the tuff water-channel of the east portico. (Photo: author.)

as gifts to temple cults. Although we perhaps should not take this as definite proof that such trees were brought into the sanctuary of Venus once the courtyard had been paved in the early first century AD, the possibility of container trees in the precinct should not be dismissed a priori.

Various measures were taken in this phase to supply and drain the sanctuary of water and to manage water use. Lead water-pipes were laid down just before the courtyard floor was sealed with the mortar paving (FIG. 17), the pipes possibly being part of a system of pressurized fountains made possible by the introduction of the aqueduct by Augustus (Ohlig, 2001). Plaster-lined masonry tanks were cut through this mortar paving against and abutting the tuff gutter in front of at least the north and east porticoes, the water flowing in the gutter being diverted into the tanks. Monuments and votive dedications on stone bases stood on top of the mortar paving in the courtyard or their foundations cut through it (FIG. 18). A number of inscribed marble plaques may have been attached to images and dedications in this phase of the sanctuary's history (Curti, 2008b: 73, fig. 4). Various sorts of coloured limestone from Tuscany and the eastern Mediterranean were used as veneer in the making of votive monuments in the sanctuary of Venus in this phase (Carroll et al., 2008). 


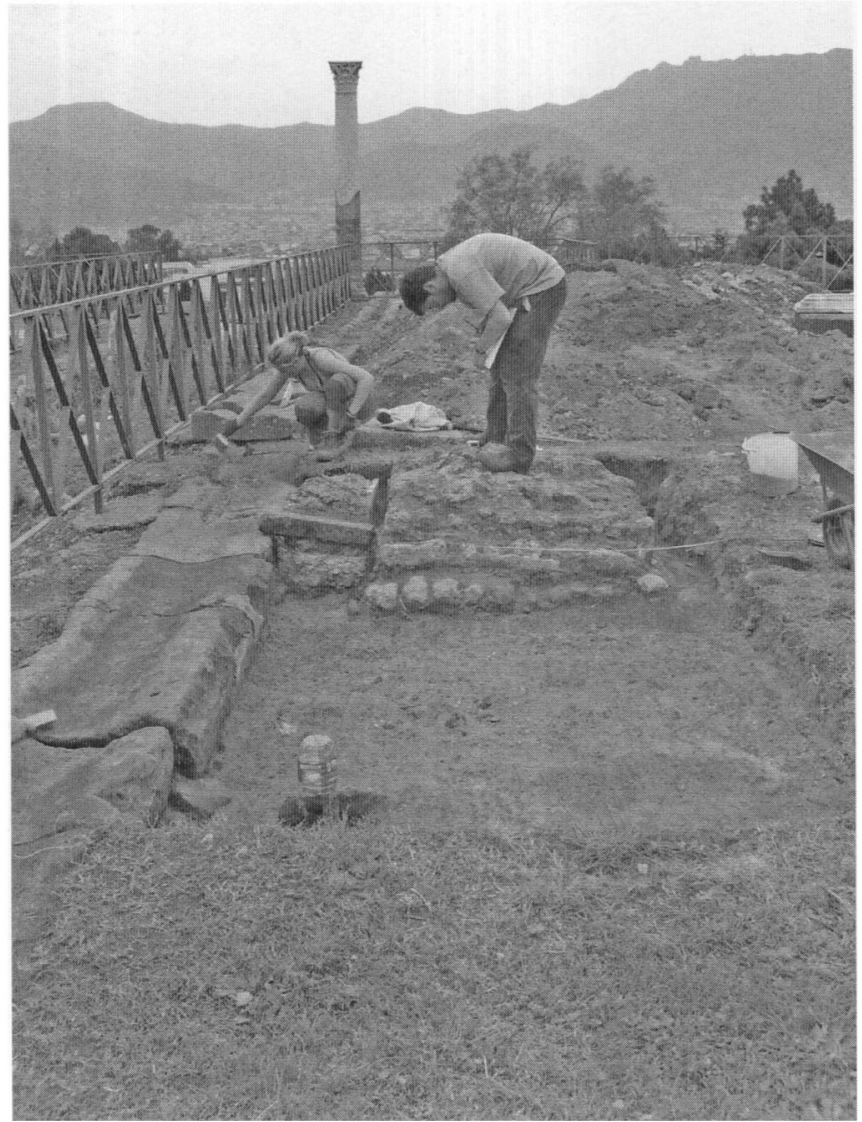

FIG. 18. View from the north of statue-bases in Trench 6 during excavation. To the left is the tuff water-channel in front of the east portico. (Photo: author.)

The sanctuary, although without its nemus in this phase, continued to be a lively focus of religious veneration and social activity. The stone gutters on the edges of the sanctuary courtyard continued to be used for drainage in the early Imperial rebuild, and they are so worn down in places as to be almost flat, having been eroded by pedestrian traffic for several decades. The central groove in many sections of the gutter even had to be re-cut and chiselled deeper in order for the stone slabs to be able to retain water (FIG. 19), the gutter in front of the southern half of the eastern portico showing the greatest erosion. It indicates a considerable volume of traffic entering the sanctuary through the main northeast gate and then proceeding down the east portico to step out into the southern half of the courtyard, where processions perhaps turned west to face the temple and the altar in front of it.

\section{SEISMiC ACTIVITY AND THE END OF THE TEMPLE OF VENUS}

The earthquake of $\mathrm{AD} 62$ and perhaps further tremors in subsequent years destroyed many buildings in Pompeii (Allison, 1995; De Simone, 1995; Lazer, 1997), among them the temple 
FiG. 19. View from the south of the tuff water-channel next to the east portico in and beyond Trench 6. Note the crudely carved and hacked area in the middle of the water-channel to make it deeper. (Photo: author.)

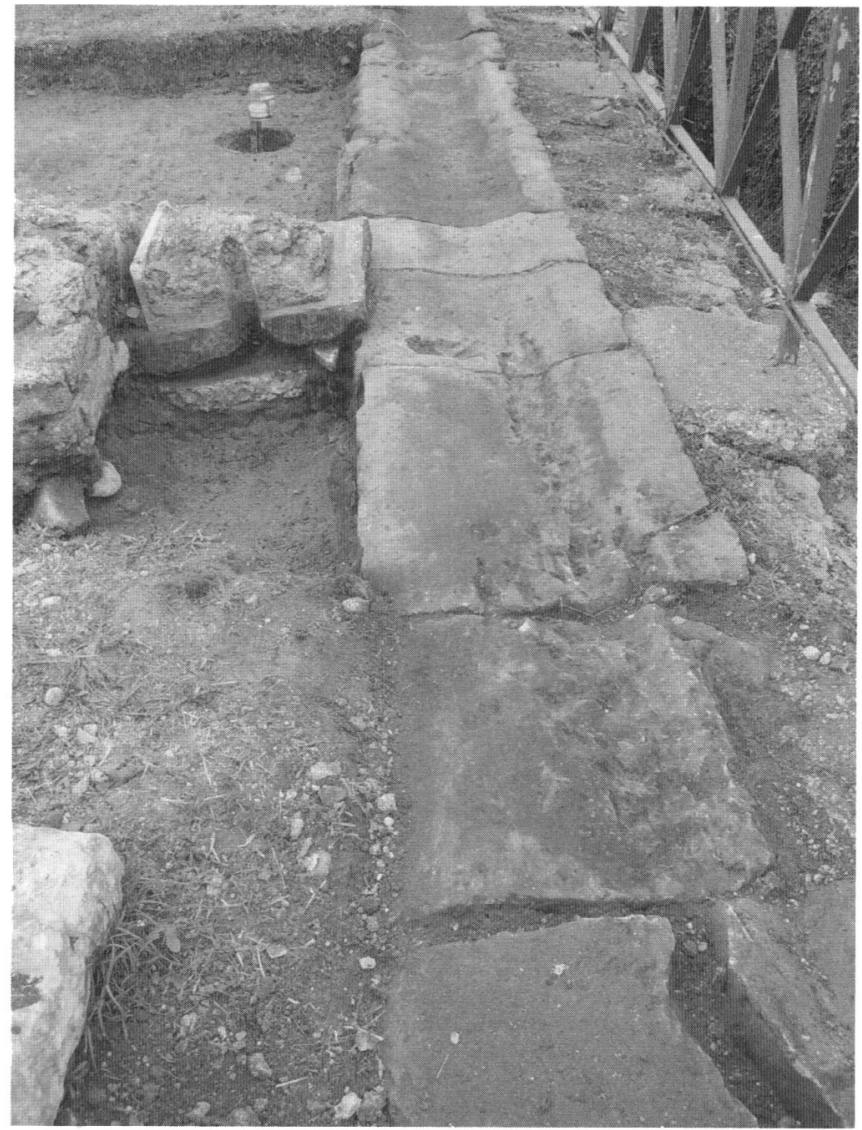

of Venus. John Dobbins (1994) and Kurt Wallat (1995) demonstrated that one of the main concerns of the inhabitants after the earthquake was to rebuild the forum. The temple of Apollo very probably still lay in ruins (Carroll and Godden, 2000: 752-3), but the debris in the precinct of Venus had been cleared and building work on the new temple and portico foundations had made considerable progress. Clearly, in addition to the forum, another main concern of the Pompeians was the sanctuary of the city's patron goddess.

After the earthquake, the builders dug a broad and deep foundation trench around the old temple, and they were in the process of erecting courses of large basalt blocks against the walls of the original building for the new structure, some of which still lie scattered in the courtyard today (Mau, 1900: 277) (FIGS 20 and 21). The northern extension of the temple cut through the old stone gutter in front of the earlier northern portico. When Vesuvius erupted in AD 79, heaps of basalt chips and debris from the cutting of the foundation blocks were left lying where they fell, offering us rare insight into the untidy appearance of a Roman building-site (FIG. 22). The old cistern under the floor of the eastern portico was now cut in half by a north-south foundation trench for the new eastern portico, and it was backfilled (FIG. 3). A 


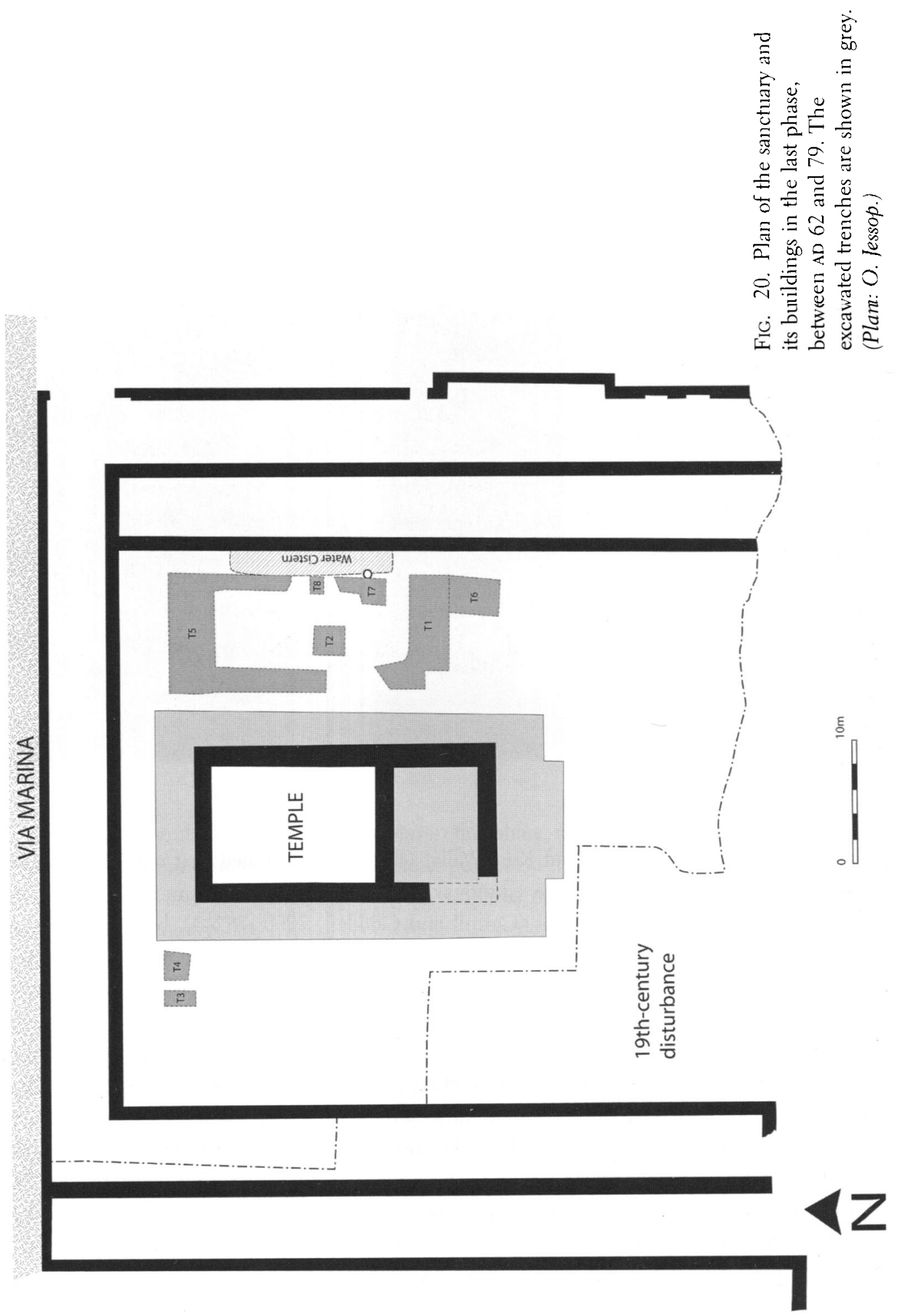




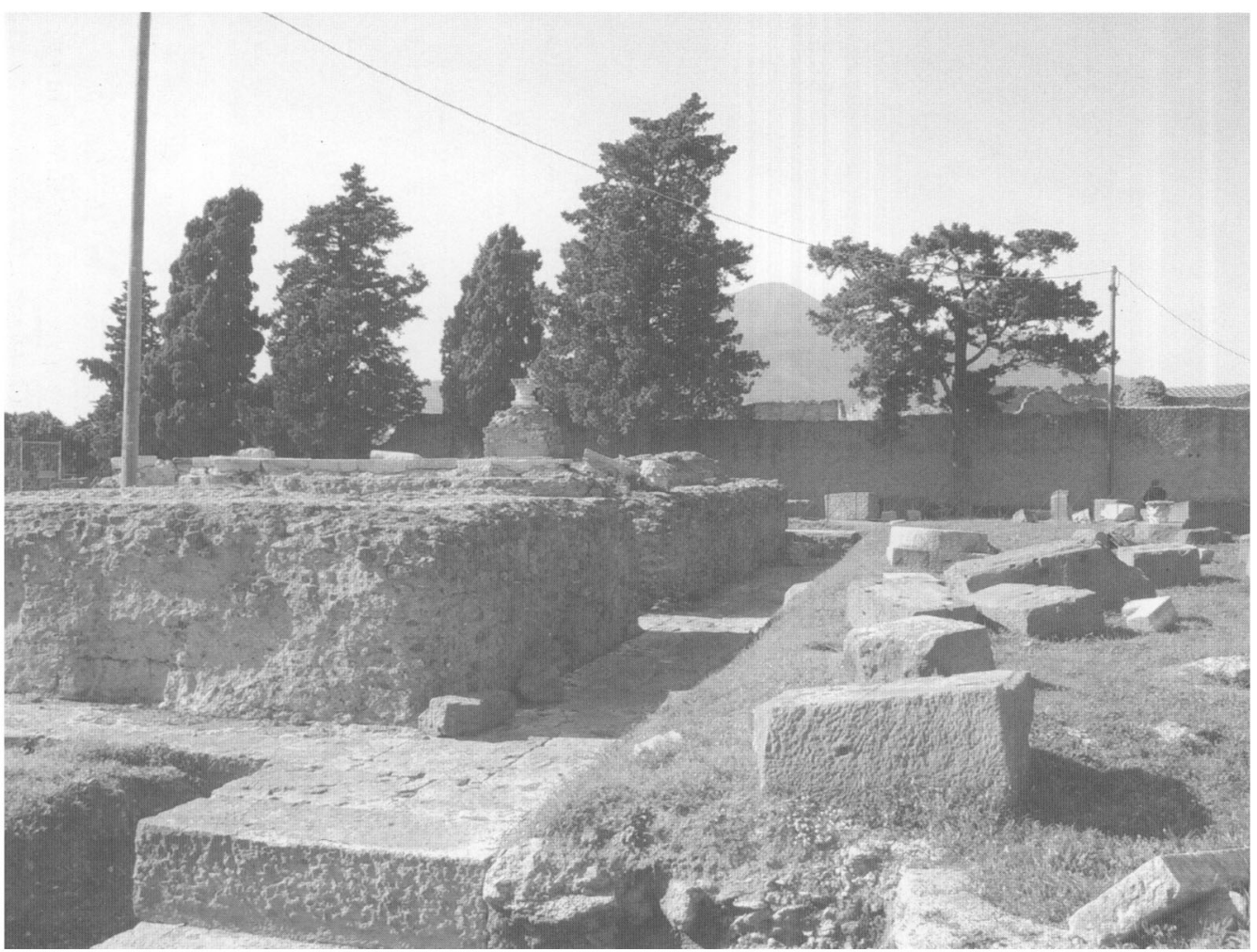

FIG. 21. View from the south of the temple as it was being enlarged after AD 62. The upright opus caementitium core is part of the mid-first-century BC temple; the still intact courses of large basalt blocks were laid into a construction trench surrounding the earliest building. The scattered basalt blocks in the courtyard are remnants of this building work. (Photo: author.)

coin of Vespasian in the cistern backfill indicates that work on the new portico cannot have begun before AD 69 (Spano, 1910: 271). ${ }^{8}$

The northern boundary of the precinct now jutted out into the Via Marina (FIG. 23), effectively reducing the amount of traffic that could travel on the road to the forum. This wall is built of yellow tuff in opus reticulatum and is devoid of any seismic damage; Maiuri and others have attributed it to the last phase of work after the earthquake (Maiuri, 1942: 65-7; Jacobelli and Pensabene, 1995-6: 46; Wolf, 2004: 196). The new eastern limit of the sanctuary encroached on a narrow street parallel to the basilica, and a secondary entrance to the sanctuary was opened in this eastem precinct wall (Richardson, 1988: 277). At the southern end of the precinct the so-called Villa Imperiale was incorporated into a new set of substructures, to push the limits of the sanctuary out over the valley below (Mau, 1900: 294-5; Maiuri, 1960: 173, fig. 8; Strocka, 1995: 177; Eschebach and Eschebach, 1995: 84-5; Jacobelli, 2001: 37-9;

8 Another cistern in the extreme west of the sanctuary, according to Eschebach and Eschebach (1995: $78)$, was also backfilled after AD 62 . 


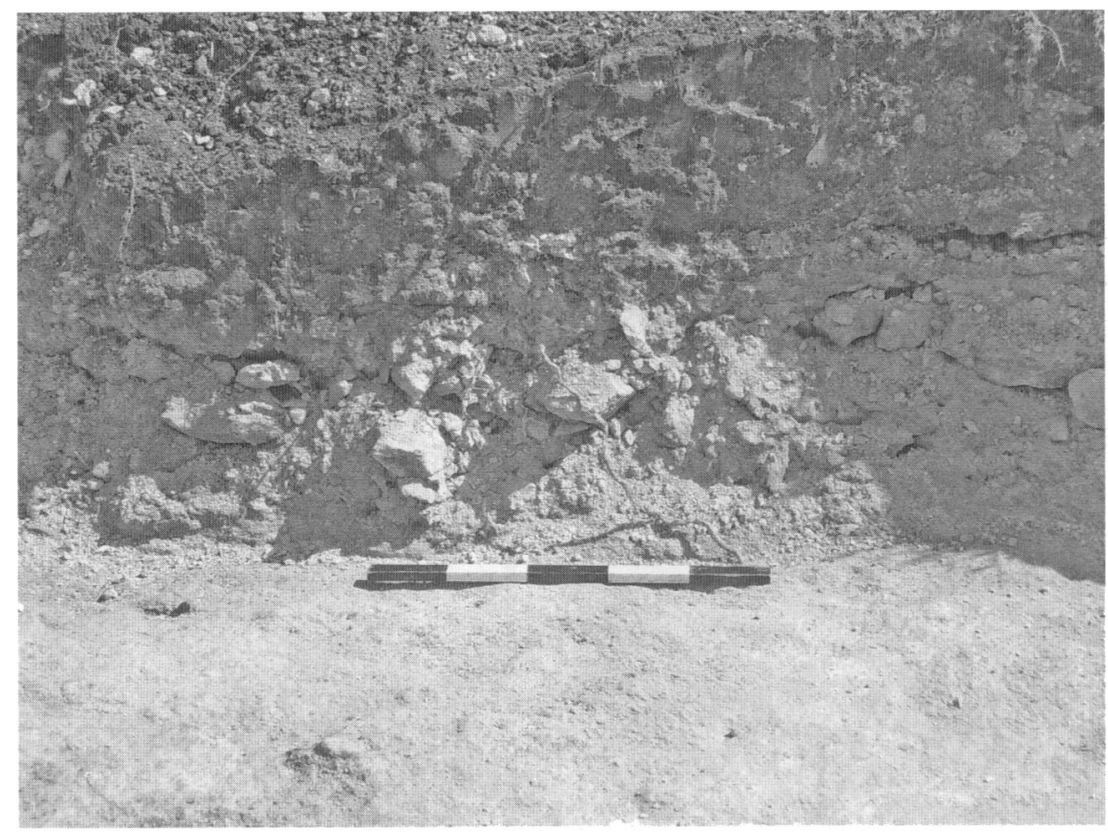

FIG. 22. Detail of the chippings and fragments of basalt (grey layer) that accumulated on top of the mortar paving (bottom) during work on the new and extended foundations of the temple after AD 62. (Photo: author.)

Ling, 2005: 93-4; Pappalardo, 2005). However, the sanctuary was never finished, and nor was its sacred grove replanted, because Vesuvius erupted while work was still ongoing. The foundation trench for the new eastern portico was still open at the time of the eruption, the original excavators finding it full of lapilli and ash from the volcanic fall-out (Mau, 1900: 272, 295; Maiuri, 1942: 67, pl. 15b).

Some parts of the Luna marble superstructure of the second phase temple, as well as material salvaged from other buildings, were being recycled for this last building, as tool marks and cuttings on some of the remaining marble friezes, cornices and column elements show (Jacobelli and Pensabene, 1995-6: 49-51; Bruno et al., 2002: 282). Significant quantities of white Luna marble offcuts confirm the carving of fresh marble or the reworking of the second phase temple decoration, and numerous chips of pink Portasanta limestone from Chios are related to the working of other monuments in the sanctuary (Carroll et al., 2008). An unfinished shaft of a Portasanta column for a votive offering (FIG. 24) and a roughly worked column drum of the same material still can be seen on site (Mau, 1900: 302; Jacobelli and Pensabene, 1995-6: cat. nos. 51-2, fig. 56; Bruno et al., 2002: 282, figs 15-16).

Whether the financial resources needed for this last rebuild were supplied entirely through local private patronage or whether the civic treasury contributed or imperial subsidies were even granted is uncertain. Graffiti from the House of Iulius Polybius (IX.13.1-3) suggest that costly gifts of gems, pearls and significant amounts of gold had been donated to the sanctuary 


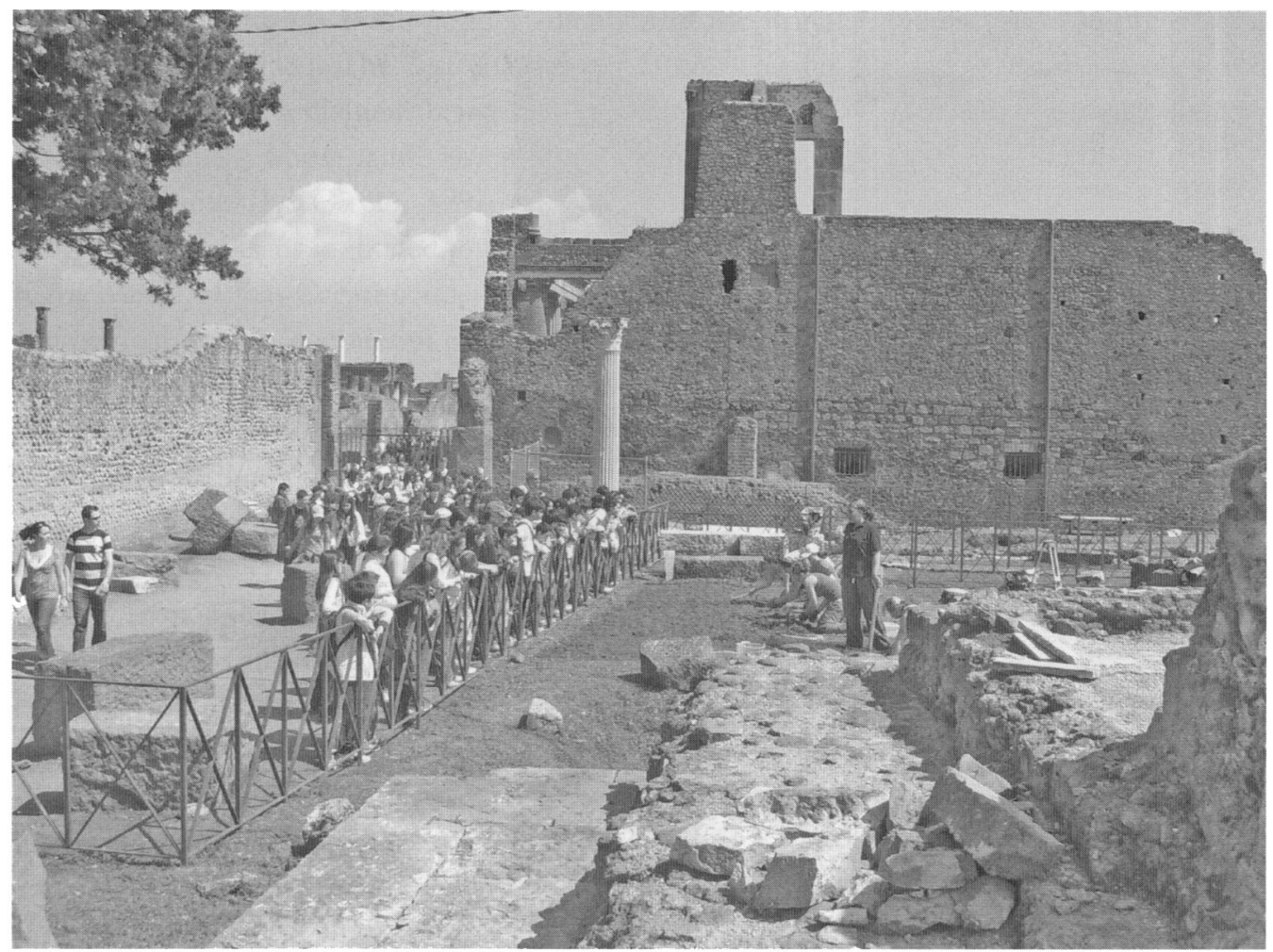

FIG. 23. Looking east to the entrance of the sanctuary from the Via Marina. The wall in the left of the photo is the extended sanctuary precinct wall built into the street after $\mathrm{AD} 62$. In the background is the basilica. (Photo: author.)

of Venus by Nero and his wife, Poppaea Sabina. A Fourth Style painting in the House of Maius Castricius in the Insula Occidentalis (VII.16.17) depicts the goddess extraordinarily decked out with opulent jewellery of gold, pearls and emeralds, perhaps a distant reflection of the gifts of the imperial couple (PPM vol. 7. Regio VII, parte II (1997), 895, fig. 12; Varriale, 2006: 439-42). A large gold oil-lamp found near the sanctuary was linked by Stefano De Caro (1998: 242-3) with such donations and interpreted as a gesture of imperial munificence and an intervention of the central government. The jury is still out on whether Nero and his Campanian wife actually visited the stricken city in AD 64, when he was in nearby Naples (Tacitus, Annals 15.33; Suetonius, Nero 20), but even if this emperor had been generous to the cult and made a personal appearance in Pompeii, such gifts hardly constitute official subsidies or government measures to assist in the restoration of the sanctuary.

Other Pompeian scholars see the hand of the Flavian government in the recovery of Pompeii in general, arguing that the imperial treasury must have supplied at least some revenue in view of a possible shortage of local civic funds (Dobbins, 1994: 693; Ling, 2005: 93). Vespasian indeed had sent a special commissioner, T. Suedius Clemens, to Pompeii, to intervene in fiscal affairs and reclaim public land from private occupancy; but how much imperial support (if any) 


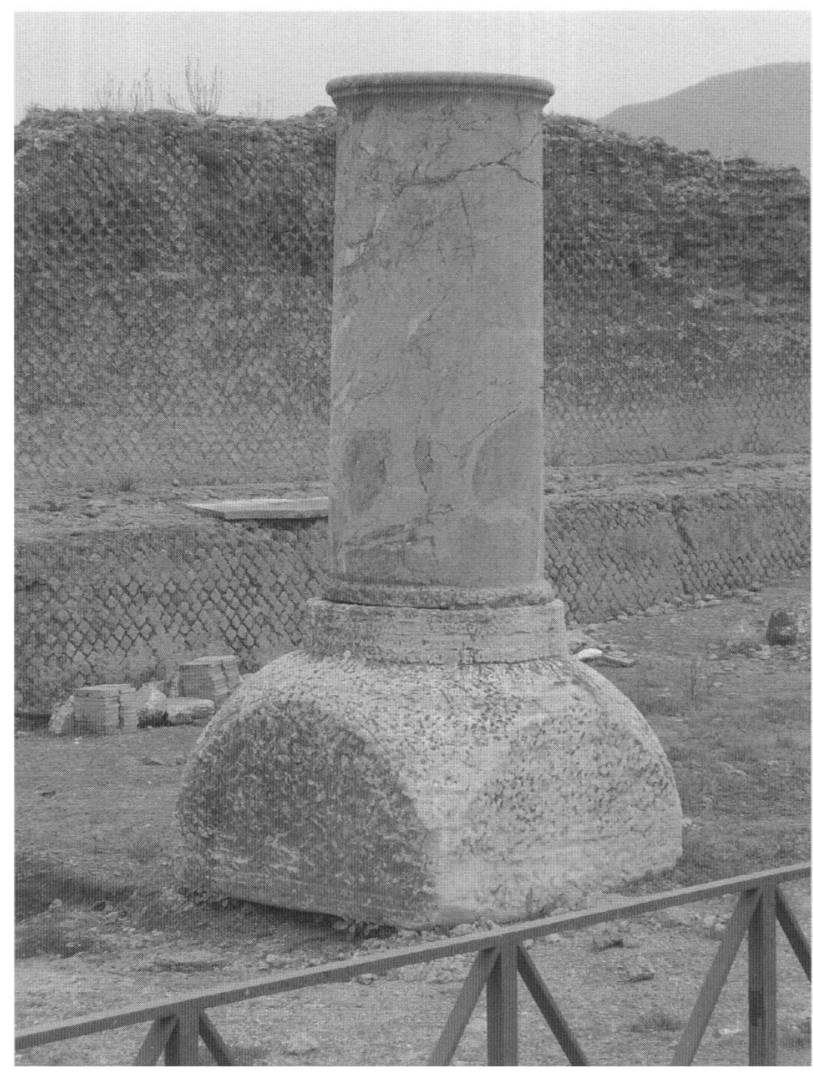

FIG. 24. Unfinished column of Portasanta limestone for a votive offering, brought in and worked on after AD 62. The column shaft rests today on an unfinished column capital of Proconnesian marble. (Photo: author.)

might have been given specifically to the cult of Venus cannot be determined (Castren, 1975: 117; Sertà, 1998; Sertà, 1999; Franklin, 2001: 156-63; Jacobelli, 2001: 44-8; Ling, 2005: 93).

\section{The sanctuary of Venus and Roman political and Civic IDENTity in PompeiI}

If the sanctuary of Venus was conceived in the years after the deduction of the colony in $80 \mathrm{BC}$, our evidence suggests that it was not until the middle of the first century $\mathrm{BC}$ that it actually was built. In order to appreciate the significance of this, we need to consider the physical consequences of the Roman acquisition of Pompeii, as well as the social and political context in which a building complex such as the landscaped sanctuary of Venus could have been constructed. Stephen Dyson (1997: 151) highlighted how little attention has focused on what he called 'the wrenching physical implications of such massive changes in property holdings and social status'. Keeping this in mind, various aspects of the circumstances and climate in early colonial Pompeii that are relevant to the conception and establishment of a monumental sanctuary of the city's tutelary goddess are considered in the following brief discussion. 
One of these aspects is the political situation of the Roman colonists and the pre-existing population of Pompeii. The first colonists in $80 \mathrm{BC}$ were the veterans of Sulla's armies and their families, their settlement being both a reward to his loyal soldiers and a punishment to defeated Pompeii, whose land was, at least partly, confiscated to become the property of the Roman colonists (Lo Cascio, 1992: 122-30; 1996). Enmity between the colonists and the indigenous Pompeians is alluded to or directly recorded in a number of written sources. Appian (Civil Wars 2.94) has Caesar condemn Sulla's confiscation policy in general as making colonists and original owners 'enemies of each other for ever'; and, as late as $62 \mathrm{BC}$, Cicero's defence of Publius Cornelius Sulla (Pro Sulla 21, 60-2) describes ongoing conflict between the municipes (Pompeians) and the colonei (Roman colonists) over confiscations and problems of land tenure, as well as limitations on the right of the local inhabitants to vote and some kind of restrictions of access in the colony (Stewart, 1995: 76-8; Lo Cascio, 1996: 117-21; Coarelli et al., 2002: 58-9; Bispham, 2007: 450). The leading men, the patroni coloniae, were not drawn from the indigenous population, but were Roman supporters and agents of Sulla who arbitrated in political affairs and defended the colony's interests, and the earliest government of colonial Pompeii was run entirely by magistrates elected from the body of new Roman colonists (Castren, 1975: 52-3, 87). That the 'privileged position of the colonists was at the expense of the Pompeians' is not disputed by Cicero (Pro Sulla 62). P. Sulla was accused of attempting to involve the municipes of Pompeii in the conspiracy of Catiline to overthrow the Senate in Rome in $63 / 62 \mathrm{BC}$, and it was perhaps the ill feeling and resentment felt by the Pompeiani (who formed the majority of the population) over injustices in their community that had been exploited in this context (Castren, 1975: 54; Stewart, 1995; Zevi, 1996: 131-2, 136).

The political organization of Roman Pompeii is also relevant to the physical and architectural development of the town. In the early years of the colony, the ordo supervised the allocation of funds by Roman magistrates for various purposes, including secular building projects. Such public building activity included the construction of the small covered theatre (CIL I $1247 /$ CIL X 844/ILS 5636; Richardson, 1988: 131-4; Adamo Muscettola, 1992: 80-1; Zanker, 1998: 65-8; Zevi, 1996: 130-1) and the forum baths (CIL X 819/ILS 641; Richardson, 1988: 147-53; Adamo Muscettola, 1992: 78-80; Zanker, 1998: 68), and the restoration and expansion of the Stabian baths (CIL I 1251/CIL X 829/ILS 5706; Richardson, 1988: 100-5; Adamo Muscettola, 1992: 78-80; Zevi, 1996: 129). All the attested Sullan building works were paid for out of the colony's public funds, apart from the amphitheatre. This was erected by Marcus Porcius and Gaius Quinctius Valgus, two of the richest supporters of Sulla and also colonial magistrates, with their private fortunes in honour of the colony and for the use of the colonists in perpetuity' (CIL I 1246/CIL X 852/ILS 5627; Castren, 1975: 88-91; Adamo Muscettola, 1992: 81-3; Zevi, 1996: 131-2; Zanker, 1998: 68-72).

Curti's hypothesis (2005: 56-60) that a military harbour (navalia) northwest of the Porta Marina may have been another Sullan building project is without substance, as the deep excavations by the University of Geneva along the so-called quay wall have retrieved no evidence for a harbour or waterway in this location c. 10-15 m above sea level (Descoeudres, 1998; Hernandez, 2005). The connection between Venus, the harbour and mercantile activity 
postulated by Curti (2008a: 48-9), therefore, cannot be upheld; if Venus 'protected the harbour', where is it? The Roman coastline was $1 \mathrm{~km}$ southwest of the Porta Marina, the immediate area of which consisted of a ridge of sand and soils, not a body of water (Pescatore et al., 2001: 81, fig. 5; Stefani and Di Maio, 2003: 167-9, fig. 11).

The first impact of the Roman colonists on Pompeii's religious architecture was felt in the forum area. Whether the temple at the north end of the forum originally had been constructed in the second century or only after $80 \mathrm{BC}$, its consecration as a temple of the Capitoline Triad after Pompeii became a Roman colony was highly significant in that political allegiance to Rome and the worship of the chief Roman state god found expression in this building (Maiuri, 1973: 10224; Richardson, 1988: 133, 144; Adamo Muscettola, 1992: 77; Dobbins, 1994: 668-71; Zanker, 1998: 55, 64; Barnabei, 2007: 53). The old Greek-style temple of Apollo on the west side of the forum, built in the sixth century $\mathrm{BC}$ and rebuilt probably in the second century BC, was now altered in the early colonial era with new stairs and a marble altar with a Latin inscription (CIL X 800) effectively rededicating the old sanctuary in the context of the city's new inhabitants and appropriating the religious traditions of the old ones (Mau, 1902: 81; Kockel, 1986: 454-6; Zevi, 1996: 128; Zanker, 1998: 65; Barnabei, 2007: 12, 15-16). Neither of these measures, however, was as ambitious as the construction of the monumental sanctuary of Venus.

The complex of buildings dedicated to Venus must have consumed considerable resources of money and labour. The timing had to be right politically and socially for the town to embark upon such an endeavour, but the economic climate also needed to be favourable, and this might not have been the case for some time after the Roman siege of the city and the settlement of colonists. A possible period of stagnating private investment by the Pompeians during this period may be reflected in domestic architecture, although the evidence is patchy. Some of the private houses destroyed in Sulla's attack in $89 \mathrm{BC}$ were not rebuilt until the mid-first century BC. Excavations have shown this to be the case with the House of the Vestals (VI.1.7), and the site just north of that house lay derelict even longer; a coin of $42 \mathrm{BC}$ found in the levelling deposits of Sullan debris used to prepare the ground for new work on the house is a valuable chronological indicator (Jones and Robinson, 2004: 115-16, 123-7; D. Robinson, pers. comm.). Elsewhere, in the southern part of the city, Paolo Carafa and Maria Teresa D'Alessio (1995-6: 139-40, 144) could not recognize any substantial post-Sullan modifications to the House of Joseph II (VIII.2.38-9) until the Augustan period. On the other hand, if Zevi (1996: 134-5) is right, the Roman colonists were investing in new or refurbished houses built on the southern edge of the town on top of the defunct city wall, in the suburbs and in the countryside, and decorating them with lavish paintings in the Second Style from about $70 \mathrm{BC}$. Recently the Villa of the Mysteries outside the Herculaneum Gate has been attributed to a great personality and high-ranking officer of Sulla's army, 'uno dei maggiorenti' of the early Sullan colony (Esposito, 2007: 459, 462).

If the colonists had expropriated land from the Pompeians in areas such as these, and especially in the countryside, on which their economic livelihood was based, one might well expect there to have been limitations on financial expenditure on the part of the indigenous population (Jongman, 1988: 144-6). After a few decades, however, the political and economic 
circumstances of the indigenous population appear to have improved. In $59 \mathrm{BC}$ Caesar pursued a policy of finally restoring confiscated estates to their original owners, settling many of his veteran soldiers, without seizing land from the local inhabitants, in Campania (Suetonius, Iulius 38; Appian, Civil Wars 3.40). ${ }^{9}$ By 55 BC at least some of the old Pompeian families, according to Cicero (Letters to his Friends 7.1.3), were acting as magistrates in the town council of the colony, sometimes through marriage with or adoption of family members of the Roman colonial magistracy (Castren, 1975: 93). Edward Bispham (2007: 450) recently has made a good case for the coexistence of a municipium of Pompeians and a colony of Roman citizens at Pompeii well into the $50 \mathrm{~s} \mathrm{BC}$, when the conflicts between the two communities finally were resolved and the municipium ceased to exist. Thus, by the middle of the century, the relationship between the two communities at Pompeii might have been stable and favourable enough for the town to begin the ambitious project of constructing the largest sanctuary ever built in Pompeii.

Finally, the cult of Venus and the importance of this goddess for Roman and local identity warrant consideration. Pompeii's Roman name - Colonia Comelia Veneria Pompeianorum - reflects both the defeat of the town by L. Cornelius Sulla in $89 \mathrm{BC}$ and the deduction of the colony nine years later under his nephew P. Sulla, as well as the close relationship the elder Sulla had with the goddess Venus (Ciprotti, 1976; Rives, 1994: 296-300). Venus, mother of the Romans and the race of Aeneas, as Lucretius (On the Nature of Things 1.1) refers to her, certainly was revered by the Roman colonists. Soon after $80 \mathrm{BC}$, she was thought important enough to be brought into election campaigns to sway the vote for a magistracy candidate (CIL IV 36/ILS 6399). Venus was tied not only to the foundation of Rome itself, but also to the dictators, statesmen and emperors who either saw Venus as their special protectress or who traced their ancestry to her. Sulla was portrayed as particularly favoured by Venus; he was champion of her descendants, the Roman people, and she was therefore important to him as the conqueror of Pompeii (Appian, Civil Wars 1.97; Zevi, 1996: 129; Keaveney, 2005: 80, 98-9, 135). Venus Genetrix, ancestress of the Romans, was of great importance to Julius Caesar, as he claimed a blood link between the gens Julia and Venus and Mars, tracing his ancestry to the alleged Trojan origins of Rome (Suetonius, Caesar 6.2). ${ }^{10}$ Caesar's heir, Octavian/Augustus, transformed Venus and Mars into national gods and reinforced them as patron deities of the Julio-Claudian imperial house (Zanker, 1988: 195-201, 215-23). In an inscription of Augustan date from the Eumachia building at Pompeii, Venus is referred to as the mother of Aeneas, and the foundation of Rome is celebrated as an expression directly relevant to Pompeii's political allegiance to Rome and its status as a Roman colony (CIL X 808/ILS 63).

9 See, for example, the Tillii who came from Arpinum to Pompeii around $50 \mathrm{BC}$, two of the family having served in Caesar's tenth legion: Castren, 1975: 93-4; D'Ambrosio and De Caro, 1983: tomb 17OS; Lo Cascio, 1992: 119.

10 Caesar's first coinage depicted Venus on one side and the flight of Aeneas from Troy on the other: Schilling, 1954: 302-3, pl. 29.5. On Caesar's temple of Venus Genetrix dedicated in $46 \mathrm{BC}$ in Rome, see: Appian, Civil Wars 2.68, 102; Cassius Dio, Roman History 43.22, 51.22.3; Ulrich, 1993: 58-71; Strocka, 2005; Meneghini and Santangeli Valenzani, 2007: 31-42. 
The goddess also might have been seen as a link between the Roman colonists and the Pompeians because Venus had been revered by the latter before Pompeii became a Roman town. Inscriptions and graffiti show that Venus here sometimes had the epithet Fisica, a word in the Oscan of the Samnite inhabitants. She is known alternatively as Venus Fisica, Venus Fisica Pompeiana or Venus Pompeiana (CIL X 928/ILS 3180; CIL IV Supp. II, 6865; CIL IV 1520; CIL IV 4007; CIL IV 2457; CIL IV 538/ILS 5138; CIL IV 36/ILS 6399; Schilling, 1954: 383-8). The meaning of the epithet Fisica is still disputed by scholars, although some make a case for Venus Fisica being the same as the Samnite and Lucanian goddess Mefitis." Whatever the epithet means, it relates to the language and perhaps religious perceptions of the pre-existing population of Pompeii. The importance of the cult to the non-colonist inhabitants can be seen in the superior status of the priesthood of Venus. The most important public priestess in Roman Pompeii was that of this goddess, and in the Augustan and JulioClaudian periods several women of the leading aristocratic, non-colonist families of Pompeii served in this office (Castren, 1975: 70-2, 96-8). ${ }^{12}$ But less illustrious sectors of Pompeian society also revered Venus. She crops up all over the city in graffiti, where she was called upon in affairs of the heart and in various other matters (CIL IV 538/ILS 5138; CIL IV 2457; CIL IV 4007).

Venus Pompeiana or Venus Fisica Pompeiana, as she is depicted at Pompeii, is a regal figure, fully clothed and magnificently dressed in deep blue, purple or reddish robes embroidered with gold, wearing a golden diadem or jewelled crown, and accompanied by her son Eros. She can also wear a turreted crown, as she does in a wall-painting on the Via dell'Abbondanza, an item worn by city personifications in the Graeco-Roman world (Plate 5). ${ }^{13}$ In this particular painting she is also a goddess of victory, being pulled triumphantly by four elephants in a chariot, a symbol also prevalent in the victory imagery of Bacchus or Liber Pater, with whom Venus is associated as a fertility goddess (Pliny, Natural History 8.4). All these depictions date to the later first century $\mathrm{AD}$, some of them to the last years of Pompeii.

In the second half of the first century BC, however, Venus was represented quite differently in Pompeii. This Venus is far less heavily draped, wearing a chiton and a light mantle, and she has none of the attributes of the later Venus Pompeiana, apart from a tiny Eros who does not stand

11 Coarelli and his colleagues (2002: 88-9) have related the epithet Fisica to the Latin fides or Oscan fisios, a term connoting a divinity who guarantees covenants and mediation, and they have connected her to Mefitis as a mediator between the heavens and the underworld. Mefitis Fisica appears at Grumentum in Lucania (CIL X 203), but not at Pompeii. On excavated sanctuaries of Mefitis, see: Bottini, Rainini and Isneghi Colazzo, 1976; Rainini, 1985; Adamesteanu and Dilthey, 1992. On Venus Fisica in general, and the various interpretations, see: Schilling, 1954: 383-8; Angelone, 1986: 29-41; Richardson, 1988: 277, n. 13; Rives, 1994: 298-300; Banabei, 2007: 45-6.

12 Mamia: CIL X 816; CIL X 998/LLS 6369; Franklin, 2001: 36-7; Barnabei, 2007: 46. Holconia: CIL X 950-1. Istacidia Rufilla: CIL X 999. Fumachia: CIL X 810/ILS 3785, CIL X 813/ILS 6368; Franklin, 2001: 33-6. Alleia: Notizie degli Scavi di Antichità (1890), 333; Bamabei, 2007: 47.

13 Via dell'Abbondanza (IX.7.7): Della Corte, 1921: 86, no. 11; Swindler, 1923: 303-6, fig. 5; Schilling, 1954: 285-6, pl. I6; Angelone, 1986: 26-7, pl. 9; Fröhlich, 1991: cat. F64, pl. 61.1; PPM vol. 9, Regio IX, parte II (1999), 776-7, figs 2-3. 
beside her but is perched on her shoulder. ${ }^{1+}$ The earliest depictions of Venus of this type from Pompeii and from a wall-painting of about $40 \mathrm{BC}$ at a villa in Terzigno probably are based on the statue of Venus Genetrix that Caesar dedicated in Rome in 46 BC (Elderkin, 1938; Strocka, 2005-6: 116-17, fig. 6; Kleiner, 2005: 151-3; Walker, 2008). Venus Genetrix was of political significance for Caesar and his heir Octavian, as they traced their lineage from her, and it is this Venus that Octavian/Augustus chose to depict in the pediment of his temple of Mars Ultor in Rome (Zanker, 1988: 196, fig. 150; Beard, North and Price, 1998: I, fig. 4.5; II, $80-2$ ). The earliest Venus in Pompeii, therefore, is shown in pose and dress closely related to the imagery and ideology of this goddess in the capital itself.

How the Samnite counterpart of Venus was depicted or imagined, we do not know. On the pediment of the temple of Dionysos (and Aphrodite?) outside Pompeii at Sant'Abbondio, dating to the late third or early second century BC, however, Aphrodite/Nenus is a voluptuous, reclining woman in diaphanous dress, and, therefore, more closely related to Hellenistic Greek depictions of the goddess than either the Republican or Imperial images of Venus at Pompeii (Elia, 1975: 121-2, fig. la-b; De Caro, 1992: 42-4, fig. on pp. 45 and 216).

In the end, although she is the patron deity of the Roman town and ancestral mother of the Romans, the Roman Venus honoured in her new temple was a divinity with whom the local Pompeians also could identify, and in their veneration of this goddess the Pompeiani and the colonei were united. When the sanctuary of Venus was built at the time of Caesar it was the largest of all temple precincts in the city, and it remained so throughout the rest of Pompeii's history. Its nemus was planned from the very beginning, and it is one of the earliest temple groves in the Roman world for which there is archaeological evidence. Located on a vast artificial terrace in the southwest comer of the town, the sanctuary with its temple, porticoes and landscaped courtyard stood as a conspicuous monument and ideological symbol of Roman Pompeii, the city known, according to Martial (Epigrams 4.44.5), as 'Venus' dwelling'. The landmark temple and the sacred grove of the city's tutelary goddess symbolized both the political identity and the divine sanction of the community of Roman Pompeii. ${ }^{15}$

14 House IX.11.1: Della Corte, 1921: 86, no. 10; Fröhlich, 1991: cat. F66, pl. 60.1-2; PPM vol. 10, Regio IX, parte III (2003), 163-5, figs 2-3; Strocka, 2005-6: 115-16. Insula Occidentalis VII.16.22 = House of M. Fabius Rufus: PPM vol. 7, Regio VII, parte II (1997), 1106-10, figs 317, 320, 321; Strocka, 2005-6: 115; Grimaldi, 2006: 401-4; Sauron, 2007: 182-4, figs 115-16; Grimaldi, 2007: 141-4, figs 15-16. The Venus in the House of M. Fabius Rufus has Egyptian details, leading Susan Walker (2008) to suggest that she is based on the statue of Cleopatra with her little son by Caesar, Caesarion, on her shoulder, the image having been set up in the temple of Venus Genetrix in Rome. On the statue of Cleopatra, see: Kleiner, 2005: 149-53, figs 9.8, 9.9.

15 I should like to thank the Soprintendenza Archeologica di Pompei, especially Pietro Giovanni Guzzo and Antonio D'Ambrosio, for permission to excavate over the years. Annamaria Ciarallo kindly allowed us to use the Laboratorio di Ricerche Applicate for our seasons of post-excavation analysis. The fieldwork would not have been possible without the financial backing of the British Academy, the University of Sheffield and the Stanley Smith Horticultural Trust. I am grateful to Steven Ellis and Gary Devore (Pompeii Archaeological Research Project: Porta Stabia), and Damian Robinson and Rick Jones (Anglo-American Project in Pompeii), for sharing some of their equipment and storage facilities with me and for useful discussions on the archaeology of Pompeii. Andrew Wallace-Hadrill, Roger Wilson and Andrew Poulter were instrumental as referees in the 
ABBREVIATIONS

PPM = Pompei Pitture e Mosaici (1990-). Rome, Istituto della Enciclopedia Italiana.

\section{REFERENCES}

Adamesteanu, D. and Dilthey, H. (1992) Maccia di Rossano. Il santuario della Mefitis. Galatina, Congedo Editore.

Adamo Muscettola, S. (1992) La trasformazione della città tra Silla e Augusto. In F. Zevi (ed.), Pompei: 75-114. Naples, Banco di Napoli.

Allison, P. (1995) On-going seismic activity and its effects on the living conditions in Pompeii in the last decades. In Archäologie und Seismologie. La regione vesuviana dal 62 al 79 d.C. Problemi archeologici e sismologici. Colloquium Boscoreale 26-27 November 1993: 183-90. Munich, Verlag Biering \& Brinkmann.

Almagro-Gorbea, M. (1982) El Santuario de Juno en Gabii. Rome, Bibliotheca Italica.

Ampolo, C. (1993) Boschi sacri e culti federali: l'esempio del Lazio. In O. Le Cazanove and J. Scheid (eds), Les bois sacrés. Actes du colloque international organisé par le Centre Jean Bérard et l'École Pratique des Hautes Études (Ve section), Naples, novembre 1989: 159-67. Naples, Centre Jean Bérard.

Anderson, J.C. (1982) Domitian, the Argiletum and the Temple of Peace. American Joumal of Archaeology 86: 101-10.

Andreae, B. (1957) Archäologische Funde im Bereich von Rom 1949-1956/57. Archäologischer Anzeiger 72: $110-358$.

Angelone, R. (1986) L'officina coactiliaria di M. Vecilio Verecundo a Pompei. Naples, Arte Tipografica.

Arthur, P. (1986) Problems of the urbanization of Pompeii: excavations 1980-1981. Antiquaries Joumal 66: 29-44.

Barat, Y. and Morize, D. (1999) Les pots d'horticulture dans le monde antique et les jardins de la villa Gallo-Romaine de Richebourg (Yvelines). In Société Française d'Étude de la Céramique Antique en Gaule. Actes du congrès de Fribourg, mai 1999: 213-36. Marseille, Société Française d'Étude de la Céramique Antique en Gaule.

Barbet, A. and Miniero, P. (1999) (eds) La villa San Marco a Stabia. Naples, Centre Jean Bérard.

successful outcome of grant applications. I am also grateful to colleagues who have contributed their expertise and time to the project: Hugh Willmott (site supervisor); Michele Forte (site supervisor); Emma-Jayne Graham (trench supervisor); Glynis Jones (palacobotany); Sarah Viner (osteology); Andrew Chamberlain (magnetometry); Oliver Jessop (plans and graphics); Jemeja Willmott (finds drawings) - all University of Sheffield; Robyn Veal (charcoal analysis, University of Sydney), Myles McCallum (ceramic analysis, St Mary's University, Halifax), Giuseppe Montana and his team (marble and limestone analysis, Università di Palermo), and Michael Joachimski (marble stable isotopes, Universität Erlangen). The on-site work of students from the Universities of Sheffield and Nottingham is warmly acknowledged. Eric Poehler kindly provided me with a detailed plan of the southwest sector of Pompeii. Finally, I should like to thank the anonymous reviewers for their comments, and the editor, Jo Crawley Quinn, for her help in seeing this paper through to publication. 
Barnabei, L. (2007) I culti di Pompei. Raccolta critica della documentazione. In Contributi di archeologia vesuviana III: 11-88. Rome, 'L'Erma' di Bretschneider.

Beard, M., North, J. and Price, S. (1998) Religions of Rome, 2 vols. Cambridge, Cambridge University Press.

Berry, J. (1998) (ed.) Unpeeling Pompeii. Studies in Region I of Pompeii. Milan, Electa.

Bispham, E. (2007) From Asculum to Actium. The Municipalization of Italy from the Social War to Augustus. Oxford, Oxford University Press.

Bon, S.E., Jones, R., Kurchin, B. and Robinson, D.J. (1997) The context of the House of the Surgeon. Investigations in Insula VI,1 at Pompeii. In S.E. Bon and R. Jones (eds), Sequence and Space in Pompeii: 32-49. Oxford, Oxbow.

Bonghi Jovino, M. (1984) Ricerche a Pompei. L'Insula 5 della Regio VI dalle origini al 79 d.C. Rome, 'L'Erma' di Bretschneider.

Bottini, A., Rainini, I. and Isneghi Colazzo, S. (1976) Valle d'Ansanto. Rocca S. Felice (Avellino). Il deposito votivo del santuario di Mefite. Notizie degli Scavi di Antichità: 359-524.

Broise, H. and Scheid, J. (1993) Étude d'un cas: le lucus Deae Diae à Rome. In O. Le Cazanove and J. Scheid (eds), Les bois sacrés. Actes du colloque international organisé par le Centre Jean Bérard et l'École Pratique des Hautes Études (Ve section), Naples, novembre 1989: 145-57. Naples, Centre Jean Bérard.

Bruno, M., Conti, L., Pensabene, P. and Turi, B. (2002) Pompeii after the AD 62 earthquake: historical, isotopic, and petrographic studies of quarry blocks in the Temple of Venus. In J.J. Herrmann, N. Herz and R. Newman (eds), Asmosia 5. Interdisciplinary Studies on Ancient Stone. Proceedings of the Fifth International Conference of the Association for the Study of Marble and Other Stones in Antiquity: 282-8. London, Archetype Publications.

Carafa, P. (1997) What was Pompeii before 200 B.C.? Excavations in the House of Joseph II, in the Triangular Forum and in the House of the Wedding of Hercules. In S.E. Bon and R. Jones (eds), Sequence and Space in Pompeii: 13-31. Oxford, Oxbow.

Carafa, P. and D’Alessio, M.T. (1995-6) Lo scavo nella Casa di Giuseppe II (VIII.2.38-39) e nel portico occidentale del Foro Triangolare a Pompei. Rapporto preliminare. Rivista di Studi Pompeiani 7: 137-52.

Carroll, M. (2003) Earthly Paradises. Ancient Gardens in History and Archaeology. London, British Museum Press.

Carroll, M. (2008) Nemus et templum. Exploring the sacred grove at the temple of Venus in Pompeii. In P.G. Guzzo and M.P. Guidobaldi (eds), Nuove ricerche archeologiche nell'area vesuviana (scavi 2003-2006). Atti del convegno Roma 1-3 febbraio 2007: 37-45. Rome, 'L'Erma' di Bretschneider.

Carroll, M. and Godden, D. (2000) The sanctuary of Apollo at Pompeii: reconsidering chronologies and excavation history. American Joumal of Archaeology 104: 743-54.

Carroll, M., Montana, G., Randazzo, L. and Giarrusso, R. (2008) Recovering evidence for the use of marble and coloured limestone in the first century $\mathrm{AD}$ in excavations at the sanctuary of Venus at Pompeii. Fasti Online Documents of Research 119: http://www.fastionline.org/docs/FOLDER-it2008-119.pdf (last consulted 23.08.2010).

Castren, P. (1975) Ordo Populusque Pompeianus. Polity and Society in Roman Pompeii. Rome, Bardi Editore. 
Ciprotti, P. (1976) Il nome e la legge di Pompei colonia romana. Cronache Pompeiane 2: 21-8.

Coarelli, F. (1986) (ed.) Fregellae. Il santuario di Esculapio. Rome, Edizioni Quasar.

Coarelli, F. (1987a) Munigua, Praeneste e Tibur. I modelli Laziali di un municipio della Baetica. Lucentum 6: 91-100.

Coarelli, F. (1987b) I santuari del Lazio in età repubblicana. Rome, La Nuova Italia Scientifica.

Coarelli, F. (1993) I luci del Lazio: la documentazione archeologica. In O. Le Cazanove and J. Scheid (eds), Les bois sacrés. Actes du colloque international organisé par le Centre Jean Bérard et l'École Pratique des Hautes Études (Ve section), Naples, novembre 1989: 45-52. Naples, Centre Jean Bérard.

Coarelli, F. (1998) Il culto di Mefitis in Campania e a Roma. In I culti della Campania antica. Atti del convegno internazionale di studi in ricordo di Nazarena Valenza Mele, Napoli 1995: 185-90. Rome, Giorgio Bretschneider Editore.

Coarelli, F., De Albentiis, E., Guidobald, M.P., Pesando, F. and Varone, A. (2002) Pompeii. New York, Riverside Book Company.

Cottica, D. and Curti, E. (2008) Il progetto di recupero ed edizione degli scavi I.E. (Impianto Elettrico) 1980-81 nel Foro di Pompei. In P.G. Guzzo and M.P. Guidobaldi (eds), Nuove ricerche archeologiche nell'area vesuviana (scavi 2003-2006). Atti del convegno Roma 1-3 febbraio 2007: 25-

6. Rome, 'L'Erma' di Bretschneider.

Curti, E. (2005) Le aree portuali di Pompei: ipotesi di lavoro. In V. Scarano Ussani (ed.), Moregine. Suburbio 'portuale' di Pompei: 51-76. Naples, Loffredo Editore.

Curti, E. (2008a) Il tempio di Venere Fisica e il porto di Pompei. In P.G. Guzzo and M.P. Guidobaldi (eds), Nuove ricerche archeologiche nell'area vesuviana (scavi 2003-2006). Atti del convegno Roma 1-3 febbraio 2007: 47-60. Rome, 'L'Erma' di Bretschneider.

Curti, E. (2008b) La Venere Fisica trionfante: un nuovo ciclo di iscrizioni dal santuario di Venere a Pompei. In Le perle e il filo. A Mario Torelli per i suoi settanta anni: 67-81. Venosa, Osanna Edizioni.

D’Ambrosio, A. and De Caro, S. (1983) Un impegno per Pompei. Fotopiano e documentazione della necropoli di Porta Nocera. Milan, Touring Club.

De Caro, S. (1992) La città sannitica. Urbanistica e architettura. In F. Zevi (ed.), Pompei: 23-46. Naples, Banco di Napoli.

De Caro, S. (1998) La lucerna d'oro di Pompei: un dono di Nerone a Venere Pompeiana. In I culti della Campania antica. Atti del convegno internazionale di studi in ricordo di Nazarena Valenza Mele, Napoli 1995: 239-44. Rome, Giorgio Bretschneider Editore.

Della Corte, M. (1921) Venus Pompeiana. Ausonia 10: 68-87.

Desbat, A. (1997) Pots horticoles antiques de Lyon et de Vienne. Revue Archéologique de l'Est 48: 311-18. Descoeudres, J.-P. (1994) Pompeii Revisited. The Life and Death of a Roman Town. Sydney, Meditarch.

Descoeudres, J.-P. (1998) The so-called quay wall north-west of Pompeii's Porta Marina. Rivista di Studi Pompeiani 9: 210-16.

De Simone, A. (1995) I terremoti precedenti l'eruzione. Nuove attestazione da recenti scavi. In Archäologie und Seismologie. La regione Vesuviana dal 62 al 79 d.C. Problemi archeologici e sismologici. Colloquium Boscoreale 26-27 November 1993: 37-43. Munich, Verlag Biering \& Brinkmann. 
Dobbins, J.J. (1994) Problems of chronology, decoration, and urban design in the Forum at Pompeii. American loumal of Archaeology 98: 629-94.

Dyson, S.L. (1997) Some random thoughts on a collection of papers on Roman archaeology. In S.E. Bon and R. Jones (eds), Sequence and Space in Pompeii: 150-7. Oxford, Oxbow.

Elderkin, G.W. (1938) The Venus Genetrix of Arcesilaus. American Joumal of Archaeology 42 (3): 371-4. Elia, O. (1975) La scultura pompeiana in tufo. Cronache Pompeiane 1: 118-43.

Eschebach, H. and Eschebach, L. (1995) Pompeji vom 7. Jahrhundert v. Chr. bis 79 n. Chr. Cologne, Böhlau Verlag.

Esposito, D. (2007) Pompei, Silla e la Villa dei Misteri. In F. Zevi, J.-M. Moret and A. Pelletier (eds), Villas, maisons, sanctuaires et tombeaux tardo-républicains: découvertes et relectures récentes. Actes du colloque international de Saint-Romain-en-Gal en l'honneur d'Anna Gallina Zevi: 441-65. Rome, Edizioni Quasar.

Fasolo, F. and Gullini, G. (1953) Il santuario della Fortuna Primigenia a Palestrina. Rome, Istituto di Archeologia.

Franklin, J.L. (2001) Pompeis Difficile Est. Studies in the Political Life of Imperial Pompeii. Ann Arbor, University of Michigan Press.

Fröhlich, T. (1991) Lararien- und Fassadenbilder in den Vesuvstädten: Untersuchungen zur 'Volkstümlichen' Pompejanischen Malerei. Mainz, von Zabern.

Fulford, M. and Wallace-Hadrill, A. (1998) Unpeeling Pompeii. Antiquity 72: 128-45.

Fulford, M. and Wallace-Hadrill, A. (1999) Towards a history of pre-Roman Pompeii: excavations beneath the House of Amarantus (I.9.11-12), 1995-8. Papers of the British School at Rome 67: $37-144$.

Ghini, G. (1993) La ripresa delle indagini al santuario di Diana a Nemi. Quaderni del Centro di Studio per l'Archeologia Etrusco-italica (Archeologia Laziale XI) 21: 277-89.

Ghini, G. (1995) Il santuario di Diana a Nemi (RM): nuove ricerche. In N. Christie (ed.), Settlement and Economy in Italy $1500 \mathrm{BC}-\mathrm{AD}$ 1500: 143-54. Oxford, Oxbow.

Ghini, G. (2000) Ricerche al santuario di Diana: risultati e progetti. In J.R. Brandt, A.-M. Leander Touati and J. Zahle (eds), Nemi - Status Quo. Recent Research at Nemi and the Sanctuary of Diana: 53-64. Rome, 'L'Erma' di Bretschneider.

Gleason, K.L. (1994) 'Porticus Pompeiana': a new perspective on the first public park of ancient Rome. Joumal of Garden History 14: 13-27.

Giuliani, C.F. (1970) Il santuario di Ercole Vincitore a Tivoli. Rome, De Luca.

Greep, S.J. (1987) Lead sling-shot from Windridge Farm, St. Albans and the use of the sling by the Roman army in Britain. Britannia 18: 183-200.

Grimaldi, M. (2006) VII 16 Insula Occidentalis 22. Casa di M. Fabius Rufus. In M. Aoyagi and U. Pappalardo (eds), Pompei (Regiones VI-VII). Insula Occidentalis I: 257-418. Naples, Valtrend Editore.

Grimaldi, M. (2007) La Casa di Marco Fabio Rufo a Pompei. In F. Zevi, J.-M. Moret and A. Pelletier (eds), Villas, maisons, sanctuaires et tombeaux tardo-républicains: découvertes et relectures récentes. Actes du colloque international de Saint-Romain-en-Gal en l'honneur d'Anna Gallina Zevi: 133-55. Rome, Edizioni Quasar. 
Grünhagen, W. (1959) Die Ausgrabungen des Terrassenheiligtums von Munigua. In Neue Deutsche Ausgrabungen im Mittelmeergebiet und im Vorderen Orient: 329-43. Berlin, Verlag Gebrüder Mann. Guldager Bilde, P. and Moltesen, M. (1997) In the Sacred Grove of Diana: Finds from the Sanctuary at Nemi. Copenhagen, Ny Carlsberg Glyptothek.

Guldager Bilde, P. and Moltesen, M. (2002) A Catalogue of Sculptures from the Sanctuary of Diana Nemorensis in the University of Pennsylvania Museum, Philadelphia. Rome, 'L'Enma' di Bretschneider.

Hanson, J.A. (1959) Roman Theater-Temples. Westport, Greenwood Press.

Hauschild, T. (1992) Los templos romanos de Munigua. In Templos romanos de Hispania (Cuadernos de arquitectura romana 1): 133-43. Murcia, Colegio Oficial de Arquitectos de Murcia/Secretariado de Publicaciones de la Universidad de Murcia.

Hernandez, A.C. (2005) Pompéi extra muros. La première campagne de fouilles. In P.G. Guzzo and M.P. Guidobaldi (eds), Nuove ricerche archeologiche a Pompei ed Ercolano. Atti del convegno internazionale. Roma 28-30 novembre 2002: 371-8. Naples, Electa Napoli.

Jacobelli, L. (2001) Pompei fuori le mura: note sulla gestione e l'organizzazione dello spazio pubblico e privato. In F. Senatore (ed.), Pompei tra Sorrento e Sarno. Atti del terzo e quarto ciclo di conferenze di geologia, storia e archeologia. Pompei, gennaio 1999-maggio 2000: 29-61. Rome, Bardi Editore.

Jacobelli, L. and Pensabene, P. (1995-6) La decorazione architettonica del tempio di Venere a Pompei: contributo allo studio e alla ricostruzione del santuario. Rivista di Studi Pompeiani 7: 45-76.

Jashemski, W.F. (1979) The Gardens of Pompeii, Herculaneum and the Villas Destroyed by Vesuvius [vol. 1]. New Rochelle, Caratzas Brothers.

Jashemski, W.F. (1981) The Campanian peristyle garden. In E.B. MacDougall and W.F. Jashemski (eds), Ancient Roman Gardens (Dumbarton Oaks Colloquium on the History of Landscape Architecture VII): 29-48. Washington DC, Dumbarton Oaks.

Jashemski, W.F. (1992) Vasa fictilia: ollae perforatae. In R.W. Wilhelm and H. Jones (eds), The Two Worlds of the Poet. New Perspectives on Vergil: 371-91. Detroit, Wayne State University Press.

Jashemski, W.F. (1993) The Gardens of Pompeii, Herculaneum and the Villas Destroyed by Vesuvius, vol. 2. New Rochelle, A.D. Caratzas.

Jashemski, W.F. (1995) Roman gardens in Tunisia: preliminary excavations in the House of Bacchus and Ariadne and in the east temple at Thuburbo Maius. American Journal of Archaeology 99: 559-76.

Jones, R. and Robinson, D. (2004) The making of an elite house: the House of the Vestals at Pompeii. Joumal of Roman Archaeology 17: 107-30.

Jongman, W. (1988) The Economy and Society of Pompeii. Amsterdam, J.C. Gieben.

Keaveney, A. (1987) Rome and the Unification of Italy. Totowa (NJ), Barnes \& Noble Books.

Keaveney, A. (2005) Sulla. The Last Republican. London, Routledge.

Kenrick, P. (1990) Form 18. In E. Ettlinger, B. Hedinger, B. Hoffmann, P.M. Kenrick, G. Pucci, K. RothRubi, G. Schneider, S. von Schnurbein and C.M. Wells, Conspectus Formarum Terrae Sigillatae Italico Modo Confectae: 82-3. Bonn, Rudolf Habelt.

Kleiner, D.E.E. (2005) Cleopatra and Rome. Cambridge (MA), Belknap Press.

Klynne, A. (2005) The laurel grove of the Caesars: looking in and looking out. In B. Santillo Frizell and A. Klynne (eds), Roman Villas around the Urbs. Interaction with Landscape and Environment. 
Proceedings of a Conference Held at the Swedish Institute in Rome, September 2004: 167-75. Rome, Swedish Institute in Rome.

Kockel, V. (1986) Archäologische Funde und Forschungen in den Vesuvstädten 2. Archäologischer Anzeiger: 443-579.

Lauter, H. (1968-9) Ein Tempelgarten? Archäologischer Anzeiger: 626-31.

Lauter, H. (1986) Die Architektur des Hellenismus. Darmstadt, Wissenschaftliche Buchgesellschaft.

Lazer, E. (1997) Pompeii A.D. 79: a population in flux? In S.E. Bon and R. Jones (eds), Sequence and Space in Pompeii: 102-20. Oxford, Oxbow.

Levi, A. (1967) Itineraria picta: contributo allo studio della Tabula Peutingeriana. Rome, 'L'Erma' di Bretschneider.

Liljenstolpe, P. and Klynne, A. (1997-8) The Imperial gardens of the villa of Livia at Prima Porta: a preliminary report on the 1997 campaign. Opuscula Romana 22-3: 127-47.

Ling, R. (2005) Pompeii. History, Life and Afterlife. Stroud, Tempus.

Lo Cascio, E. (1992) La società pompeiana dalla città sannitica alla colonia romana. In F. Zevi (ed.), Pompei: 115-30. Naples, Banco di Napoli.

Lo Cascio, E. (1996) Pompei dalla città sannitica alla colonia sillana: le vicende istituzionali. In M. Cébeillac-Gervasoni (ed.), Les élites municipales de l'Italie péninsulaire des Gracques à Néron: 110-23. Naples/Rome, Centre Jean Bérard/École Française de Rome.

Macaulay-Lewis, E. (2006) The role of ollae perforatae in understanding horticulture, planting techniques, garden design and plant trade in the Roman world. In J.-P. Morel, J.T. Juan and J.C. Matamala (eds), The Archaeology of Crop Field and Gardens. Proceedings of the First Conference on Crop Fields and Gardens Archaeology, Barcelona 2006: 207-19. Bari, Edipuglia.

Macaulay-Lewis, E. (2008) The fruits of victory: generals, plants and power in the Roman world. In E. Bragg, L.I. Hau and E. Macaulay-Lewis (eds), Beyond the Battlefields. New Perspectives on Warfare and Society in the Graeco-Roman World: 206-24. Cambridge, Cambridge Scholars Publishing.

Magalhaes, M.M. (1999) Le iscrizioni e l'area funeraria dei Q. e C. Poppaei a Stabiae (loc. Calcarella di Privati). Rivista di Studi Pompeiani 10: 224-35.

Maiuri, A. (1942) L'ultima fase edilizia di Pompei. Rome, Istituto di Studi Romani.

Maiuri, A. (1948) Introduzione allo studio di Pompei. La città ed i monumenti pubblici Naples, Istituto Poligrafico dello Stato.

Maiuri, A. (1960) Sterro dei cumuli e isolamento della cinta murale. Contributo all'urbanistica della città dissepolta. Bollettino d'Arte 45: 166-79.

Maiuri, A. (1973) Alla ricerca di Pompei preromana. Naples, Società Editrice Napoletana.

Marcattili, F. (2006) Un tempio di Esculapio a Pompei. Strutture, divinità e culti del cosiddetto tempio di Giove Meilichio. In Contributi di archeologia vesuviana II: 9-76. Rome, 'L'Erma' di Bretschneider.

Mau, A. (1900) Der Tempel der Venus Pompeiana. Jahrbuch des Deutschen Archäologischen Insituts 15: $270-308$.

Mau, A. (1902) Pompeii. Its Life and Art. London, MacMillan.

Meneghini, R. (2006) I Fori Imperiali: ipotesi ricostruttive ed evidenze archeologica. In L. Haselberger and J. Humphrey (eds), Imaging Ancient Rome. Documentation - Visualisation - Imagination: 144-62. Portsmouth (RI), Journal of Roman Archaeology. 
Meneghini, R. and Santangeli Valenzani, R. (2007) I Fori Imperiali. Gli scavi del Comune di Roma (1991-2007). Rome, Viviani Editore.

Messineo, G. (1984) Ollae perforatae. Xenia 8: 65-82.

Newsome, D.J. (2009) Review of R. Meneghini and R. Santangeli Valenzani (2007), I Fori Imperiali. Gli scavi del Comune di Roma (1991-2007). Rosetta 6: 63-73.

Noack, F. and Lehmann-Hartleben, K. (1936) Baugeschichtliche Untersuchungen am Stadtrand von Pompeji. Berlin, Walter de Gruyter.

Ohlig, C.P.J. (2001) De Aquis Pompeionum. Das Castellum Aquae in Pompeji: Herkunft, Zuleitung und Verteilung des Wassers. Nijmegen, Books on Demand GmbH.

Pappalardo, U. (2005) Nuove ricerche nella 'Villa Imperiale' a Pompei. In P.G. Guzzo and M.P. Guidobaldi (eds), Nuove ricerche archeologiche a Pompei ed Ercolano. Atti del convegno intermazionale. Roma 28-30 novembre 2002: 331-8. Naples, Electa Napoli.

Pappalardo, U. and Aoyagi, M. (2006) L'Insula Occidentalis. Una sintesi delle conoscenze. In M. Aoyagi and U. Pappalardo (eds), Pompei (Regiones VI-VII). Insula Occidentalis I: 17-29. Naples, Valtrend Editore.

Pescatore, T., Senatore, M.R., Capretto, G. and Lerro, G. (2001) Holocene coastal environments near Pompeii before the A.D. 79 eruption of Mount Vesuvius, Italy. Quaternary Research 55: 77-85.

Pollard, G.A. (2009) Pliny's Natural History and the Flavian Templum Pacis. Botanical imperialism in first-century C.E. Rome. Joumal of World History 203: 309-38.

Rakob, F. (1976) Hellenismus in Mittelitalien. Bautypen und Bautechnik. In P. Zanker (ed.), Hellenismus in Mittelitalien. Kolloquium in Göttingen vom 5. bis 9. Juni 1974: 366-86. Göttingen, Vendenhoeck \& Ruprecht.

Rainini, I. (1985) Il santuario di Mefite in Valle D'Ansanto. Rome, Giorgio Bretschneider.

Richardson, L. (1988) Pompeii. An Architectural History. Baltimore, Johns Hopkins University Press.

Rives, R. (1994) Venus Genetrix outside Rome. Phoenix 48: 294-306.

Rizzo, G. (2001) Le anfore del giardino del tempio. In F. Villedieu (ed.), Il giardino dei Cesari: dai palazzi antichi alla Vigna Barberini sul monte Palatino. Scavi dell'́́cole Française de Rome, 1985-1999: 98. Rome, Edizioni Quasar.

Rizzo, S. (2001) Indagini nei fori Imperiali. Oroidrografia, foro di Cesare, foro di Augusto, templum Pacis. Römische Mitteilungen 108: 215-44.

Robinson, M. (2007) Roman ground force. Oxford Today 19. http://www.oxfordtoday.ox.ac.uk/2006-07/ v19n3/07.shtml (last consulted 23.08.2010).

Sauron, G. (2007) La pittura allegorica a Pompei. Lo sguardo di Cicerone. Milan, Jaca Book.

Scheid, J. (1993) Lucus, nemus. Qu'est-ce qu'un bois sacré? In O. Le Cazanove and J. Scheid (eds), Les bois sacrés. Actes du colloque international organisé par le Centre Jean Bérard et l'École Pratique des Hautes Études (Ve section), Naples, novembre 1989: 13-20. Naples, Centre Jean Bérard.

Schilling, R. (1954) La religion romaine de Vénus depuis les origines jusqu'au temps d'Auguste. Paris, E. de Boccard.

Sear, D.R. (1982) Greek Imperial Coins. London, Seaby.

Sear, F. (1983) Roman Architecture. Ithaca, Cornell University Press.

Sertà, C.A. (1998) La ordinatio epigrafica sulla stele pompeiana di T. Suedius Clemens fuori Porta Ercolano. Rivista di Studi Pompeiani 9: 229-34. 
Sertà, C.A. (1999) La ordinatio epigrafica sulla stele pompeiana di T. Suedius Clemens fuori Porta Vesuvio. Rivista di Studi Pompeiani 10: 204-10.

Sogliano, A. (1899) Pompei. Relazione degli scavi fatti durante î mese di gennaio 1899. Notizie degli Scavi di Antichità: 17-24.

Sogliano, A. (1900) Pompei. Relazione degli scavi fatti durante il mese di gennaio 1900. Notizie degli Scavi di Antichità: 27-31.

Spano, G. (1910) Pompei. Notizie degli Scavi di Antichità: 270-1.

Stara-Tedde, G. (1905) I boschi sacri dell'antica Roma. Bullettino della Commissione Archeologica Comunale di Roma 33: 189-232.

Stefani, G. and Di Maio, G. (2003) Considerazioni sulla linea di costa del 79 d.C. e sul porto dell'antica Pompei. Rivista di Studi Pompeiani 14: 141-96.

Stewart, R. (1995) Catiline and the crisis of 63-60 B.C. The Italian perspective. Latomus 54: 62-78.

Strocka, V.M. (1995) Die Chronologie des vierten Stils, von keinem Erdbeben erschüttert. In Archäologie und Seismologie. La regione Vesuviana dal 62 al 79 d.C. Problemi archeologici e sismologici. Colloquium Boscoreale 26-27 November 1993: 175-80. Munich, Verlag Biering \& Brinkmann.

Strocka, V.M. (2005) Das Fassaden-Motiv des Venus-Genetrix-Tempels in Rom: Bedeutung und Nachwirkung. In S.T.A.M. Mols and E.M. Moormann (eds), Ommi Pede Stare. Saggi architettonici e circumvesuviani in memoriam los de Waele: 153-67. Naples, Eilecta Napoli.

Strocka, V.M. (2005-6) Troja - Karthago - Rom. Ein vonergilisches Biłdprogramm in Terzigno bei Pompeji. Römische Mitteilungen 112: 79-120.

Swindler, M.H. (1923) Venus Pompeiana and the new Pompeian frescoes. American loumal of Archaeology 27: 302-13.

Thompson, D.B. (1937) The garden of Hephaistos. Hesperia 6: 396-425.

Ulrich, R.B. (1993) Julius Caesar and the Creation of the Forum Iulium. American Joumal of Archaeology 97: 49-80.

Varriale, I. (2006) VII 16 Insula Occidentalis 17. Casa di Maius Castricius. In M. Aoyagi and U. Pappalardo (eds), Pompei (Regiones VI-VII). Insula Occidentalis I: 419-504. Naples, Valtrend Editore.

Villedieu, F. (2001a) (ed.) Il giardino dei Cesari: dai palazzi antichi alla Vigna Barberini sul monte Palatino. Scavi dell'École Française de Rome, 1985-1999. Rome, Edizioni Quasar.

Villedieu, F. (200lb) I giardini del tempio. In F. Villedieu (ed.), Il giardino dei Cesari: dai palazzi antichi alla Vigna Barberini sul monte Palatino. Scavi dell'École Française de Rome, 1985-1999: 94-7. Rome, Edizioni Quasar.

Walker, S. (2008) Cleopatra in Pompeii? Papers of the British School at Rome 76: 35-46, 345-8.

Wallat, K. (1995) Der Zustand des Forums von Pompeji am Vorabend des Vesuvausbruchs 79 n. Chr. In Archäologie und Seismologie. La regione Vesuviana dal 62 al 79 d.C. Problemi archeologici e sismologici. Colloquium Boscoreale 26-27 November 1993: 75-92. Munich, Verlag Biering \& Brinkmann.

Williams L.ehmann, P. (1954) The setting of Hellenistic temples. Journal of the Society of Architectural Historians $13(4)$ : 15-20.

Wolf, M. (2004) Tempel und Macht in Pompeji. In E.L. Schwandner and K. Rheidt (eds), Architektur der Macht - Macht der Architektur: 190-9. Mainz, von Zabern. 
Wroth, W. (1899) A Catalogue of the Greek Coins in the British Museum. Galatia, Cappadocia, and Syria. London, Trustees of the British Museum.

Zachos, K.L. (2003) The Tropaeum of the sea-battle of Actium at Nikopolis. Interim report. Joumal of Roman Archaeology 16: 64-92.

Zanker, P. (1988) The Power of Images in the Age of Augustus. Ann Arbor, University of Michigan Press. Zanker, P. (1998) Pompeii. Public and Private Life. Cambridge (MA), Harvard University Press.

Zevi, F. (1996) Pompei dalla città sannitica alla colonia sillana: per un'interpretazione dei dati archeologici. In M. Cébeillac-Gervasoni (ed.), Les élites municipales de l'Italie péninsulaire des Gracques à Néron: 125-38. Naples/Rome, Centre Jean Bérard/École Française de Rome. 


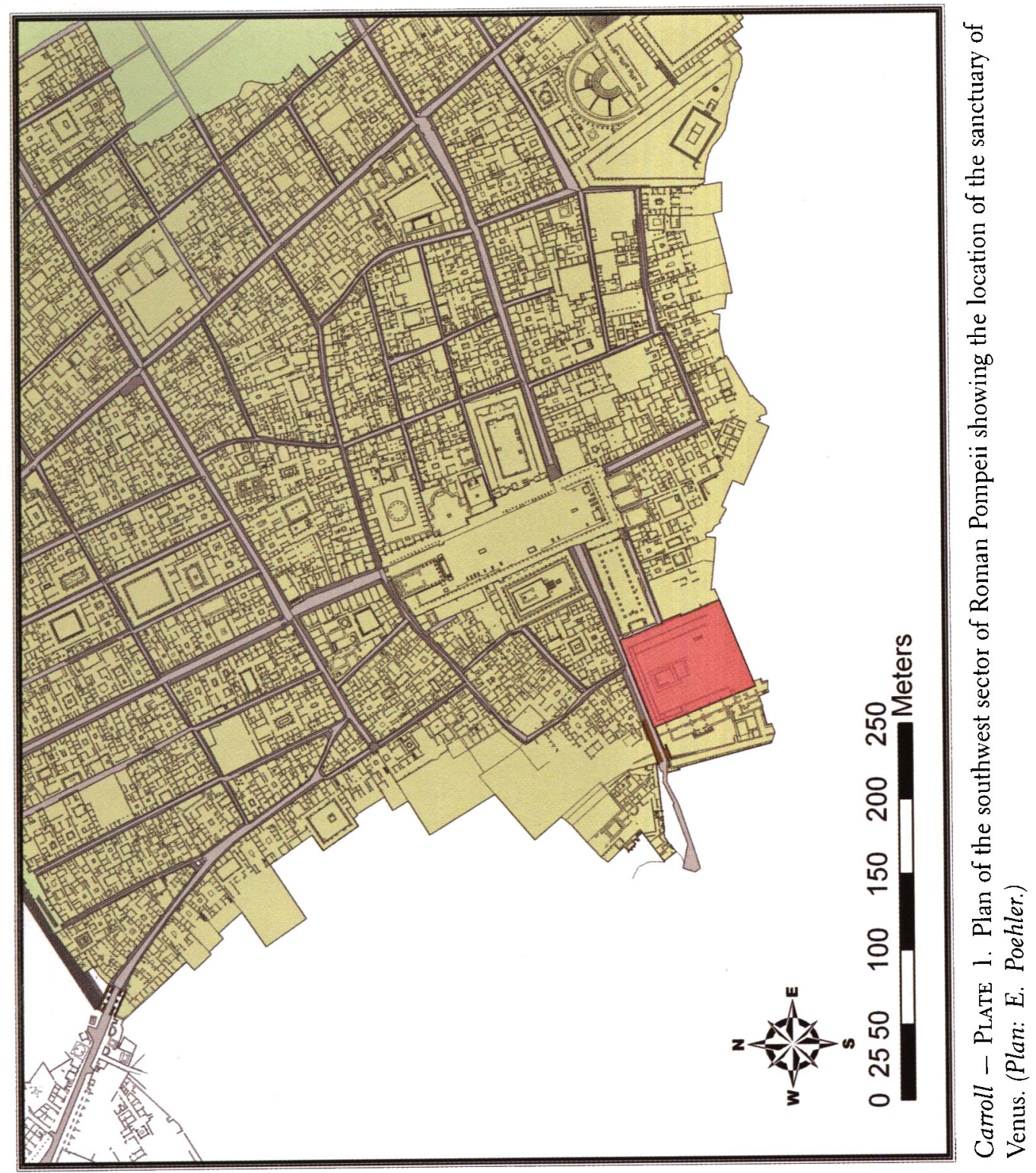




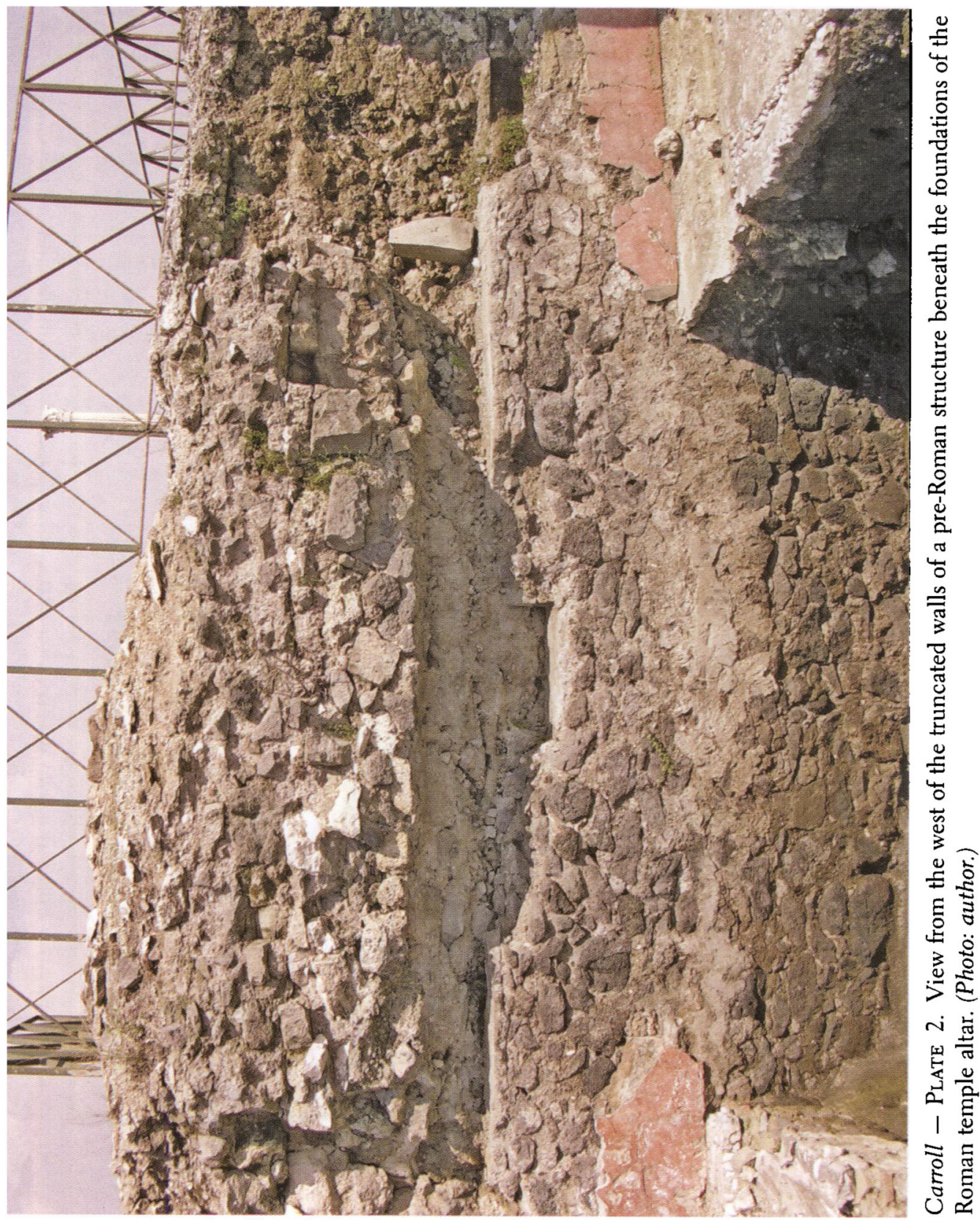




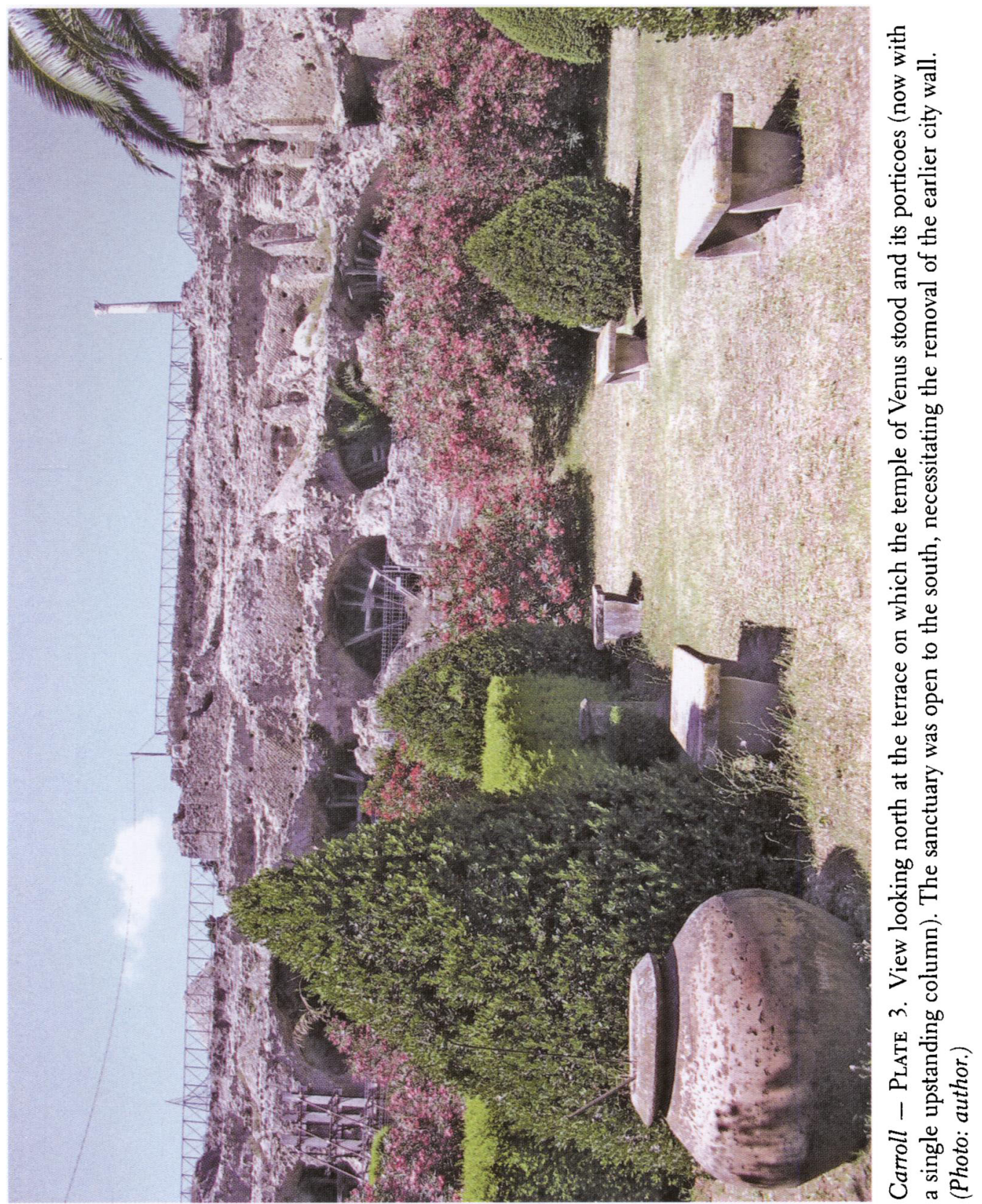




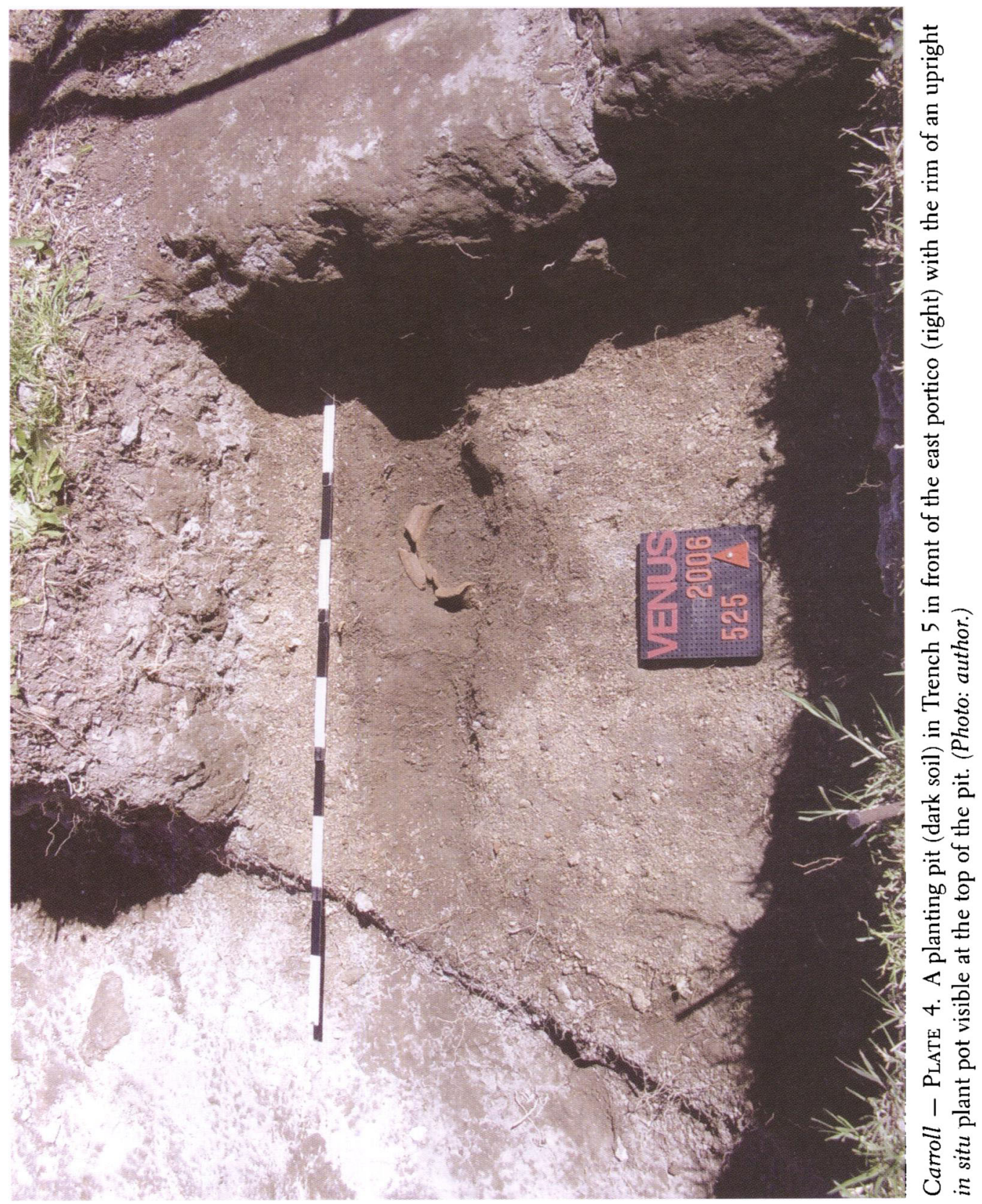




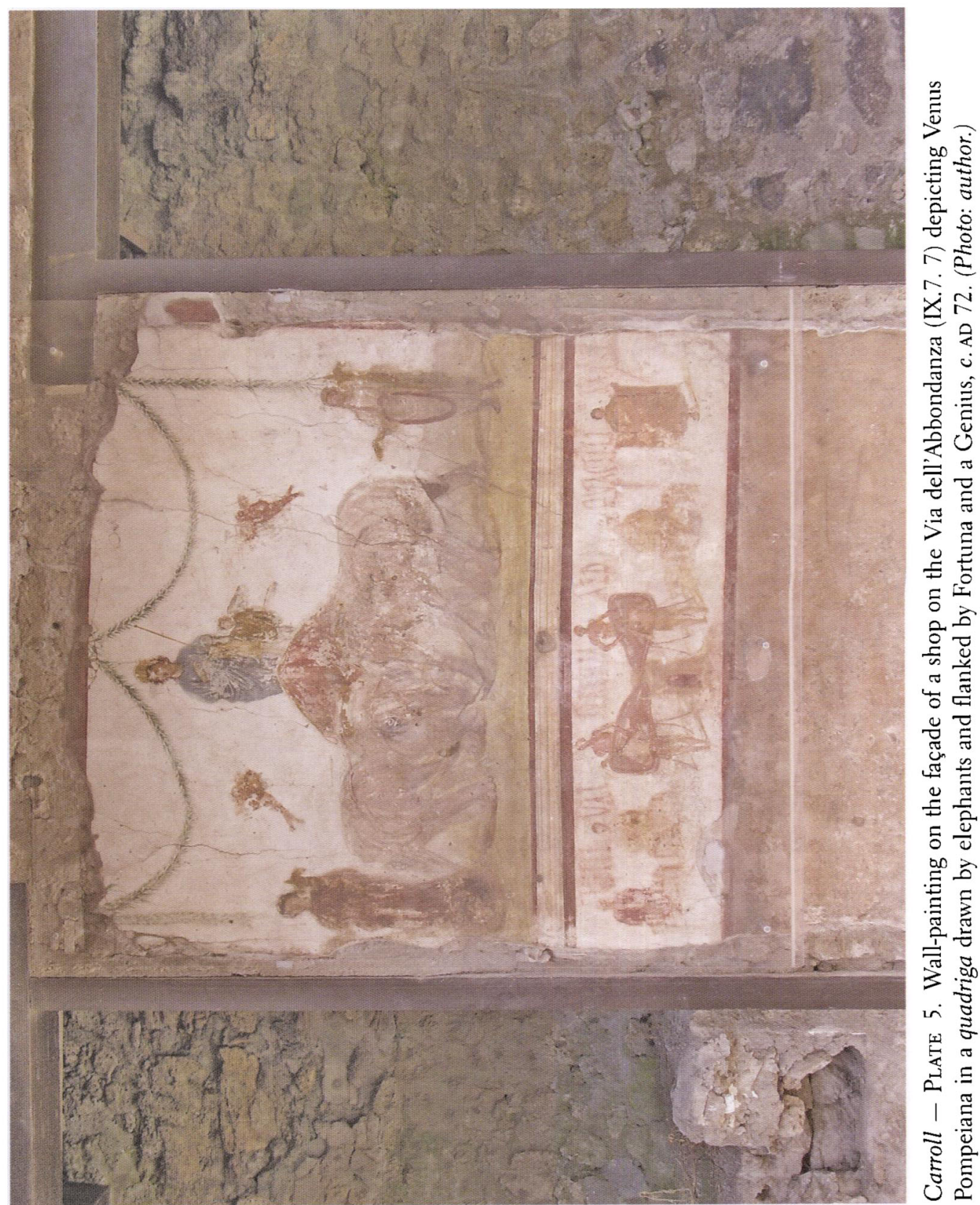

